Research paper

\title{
Pervasive early diagenetic dolomitization, subsequent hydrothermal alteration, and late stage hydrocarbon accumulation in a Middle Triassic carbonate sequence (Szeged Basin, SE Hungary)
}

\author{
István Garaguly ${ }^{\mathrm{a}, *}$, Andrea Varga ${ }^{\mathrm{a}}$, Béla Raucsik ${ }^{\mathrm{a}}$, Félix Schubert ${ }^{\mathrm{a}}$, György Czuppon ${ }^{\mathrm{b}}$, \\ Robert Frei ${ }^{\text {c,d }}$

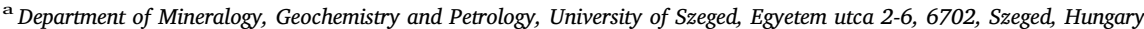 \\ ${ }^{\mathrm{b}}$ Institute for Geological and Geochemical Research, Research Centre for Astronomy and Earth Sciences, Hungarian Academy of Sciences, Budapest, Budaörsi út 45, H- \\ 1112, Hungary \\ ${ }^{\mathrm{c}}$ Department of Geosciences and Natural Resource Management, University of Copenhagen, ØsterVoldgade10, 1350, Copenhagen, Denmark \\ ${ }^{\mathrm{d}}$ Nordic Center for Earth Evolution (NordCEE), Copenhagen, Denmark
}

\section{A R T I C L E I N F O}

\section{Keywords:}

Pannonian basin

Middle Triassic

Reflux dolomitization

Hydrothermal alteration

Metamorphogenic fluid

Saddle dolomite

Fluid flow

\begin{abstract}
A B S T R A C T
The Middle Triassic shallow marine carbonates of the SE Pannonian Basin (Szeged Dolomite Formation) show evidence for multistage dolomitization and a complex diagenetic history. In first stage the whole sequence was completely dolomitized by reflux of slightly evaporated seawater. This process took place from the near surface till shallow burial realms and resulted in the formation of both fabric-preserving and fabric-destructive dolomite types.
\end{abstract}

In the following stage nonplanar matrix dolomite and saddle dolomite cement were formed in the intermediate and/or deep burial realm. These later dolomite phases are likely generated by invasion of exotic fluids at relatively high temperature evidenced from the fluid inclusion homogenization temperatures, and stable isotope compositions. Vuggy, fracture, and solution enhanced porosity are also related to this local hydrothermal event. Microthermometry performed on saddle dolomite-hosted primary fluid inclusions confirm the presence of hot (138-235 ${ }^{\circ} \mathrm{C}$ ) and moderately saline brines (4.1-8.7 mass $\% \mathrm{NaCl}$ equivalent). The calculated $\delta^{18} \mathrm{O}_{\text {water }}$ and the measured $\delta \mathrm{D}_{\text {water }}$ values of the fluid inclusions from the saddle dolomite cement together with the relatively low salinity values indicate a metamorphogenic (and/or magmatic) origin of the hydrothermal fluid that probably was channeled along the Upper Cretaceous subhorizontal overthrust zones.

The pores formed by the leaching effect of these hydrothermal fluids were subsequently partly occluded by meteoric calcite during the Paleogene-Middle Miocene subaerial exposure but a remarkable part was preserved, and currently serves as reservoir space.

Such an integrated study of the different dolomite and porosity types, the understanding of their genesis, and timing relative to hydrocarbon maturation and migration could aid in exploration and development.

\section{Introduction}

Pervasive dolomitization of a carbonate sequence is commonly the result of multiphase processes (Sun, 1994; Budd, 1997; Warren, 2000; Machel, 2004). These different dolomitization mechanisms are at the center of interest since decades due to the scientific significance and high economic value of dolomite bodies. Dolomitization is one of the most significant diagenetic processes that may lead to the modification of original porosity and permeability of a carbonate body, thus controlling the most important reservoir properties (Machel, 2004; Davies and Smith, 2006).

Most of the massive dolostone reservoirs were initially formed by early diagenetic processes that mainly related to seawater (Sun, 1994; Qing et al., 2001; Machel, 2004), however, in recent decades, there is an increasing interest in structurally controlled hydrothermal dolomite bodies due to their excellent potential as reservoirs and hosts to Mississippian Valley-type (MVT) ore deposits (Davies and Smith, 2006). Most documented hydrothermal dolomite reservoirs occur in limestones (Smith, 2006; Davies and Smith, 2006; Ronchi et al., 2012; Gomez-Rivas et al., 2014; Jacquemyn et al., 2014; Sirat et al., 2016;

\footnotetext{
* Corresponding author.

E-mail address: garagulyistvan@gmail.com (I. Garaguly).
} 
Hips et al., 2016; Mansurbeg et al., 2016) because the hydrothermal alteration is less obvious in the case of completely dolomitized regional formations. Despite this, they are probably at least as common as hydrothermally dolomitized limestones (e.g., Nader et al., 2004; Lonnee and Machel, 2006; Guo et al., 2016; Jiang et al., 2016).

The Hungarian part of the Pannonian Basin is a mature exploration area where the reservoir rocks are highly variable (Dank, 1988; Kókai and Pogácsás, 1991). The Middle Triassic carbonate sequences in the southeastern Pannonian Basin were pervasively dolomitized and are attractive targets for hydrocarbon exploration (Bércziné Makk, 1986; Garaguly et al., 2017). Nonetheless, the dolomitization mechanisms and origins of these dolomite rocks have not been investigated and explained yet, only dolomite occurrences of the northwestern part of the Pannonian Basin, belonging to the Alcapa mega-unit, have extensively been studied (e.g., Haas et al., 2015, 2017; Hips et al., 2015, 2016).

In this study, detailed macroscopic, microscopic, and cathodoluminescence petrography, geochemical investigations (including determination of carbon, oxygen, and strontium isotopic composition of carbonates as well as hydrogen isotopic composition of fluid inclusion hosted waters), and fluid inclusion microthermometry, as well as Raman microspectroscopy were carried out on the aforementioned Middle Triassic dolomite samples cored from a small natural gas reservoir. These data allowed to identify the main dolomitization mechanisms, the timing of a subsequent hydrothermal alteration, as well as the flow regimes, sources, and chemistries of the involved fluids.

The main significance of this case study derives from the following points: (1) presenting a complex diagenetic history including multiple dolomitization and alteration, porosity formation and charging of hydrocarbons into a natural gas reservoir; (2) application and integration of Raman spectroscopy and hydrogen isotope data measured from fluid inclusions into a complex diagenetic context; (3) demonstration of geochemical evidence for the significance of metamorphic and/or magmatic fluids in the hydrothermal alteration of a dolomite body.

\section{Geological setting}

\subsection{Regional geology}

The Pannonian Basin is a young depression within the European Alpine-Carpathian orogenic belt filled predominantly with Neogene formations (Fig. 1). Due to its complex Mesozoic to Neogene evolution (e.g., Csontos et al., 1992; Tari et al., 1999; Csontos and Vörös, 2004; Schmid et al., 2008), the Pannonian Basin consists of several deep subbasins that are separated by uplifted basement highs (e.g., Tari et al., 1999; Juhász et al., 2002; Matenco and Radivojević, 2012). One of these sub-basins is the so-called Szeged Basin, where the pre-Cenozoic basement is made up by Variscan metamorphic rocks, Upper Paleozoic to Lower Triassic siliciclastic formations as well as Middle Triassic shallow marine mudrocks and carbonates. Due to tectonically-induced uplift and intense denudation during the Late Cretaceous and Early Neogene, the post-Triassic Mesozoic formations are totally absent (Bércziné Makk, 1986). The studied Mórahalom-1 (M - 1) well is located in the southern margin of the Szeged Basin (Hungary) (Fig. 2).

Based on regional correlation studies and tectonic history of the Pannonian Basin, the basement of the Szeged Basin belongs to the Tisza mega-unit (Tisia composite terrane or Tisia microcontinent, as referred elsewhere) that is a large lithosphere block with complex internal structure (e.g., Haas and Péró, 2004 and references therein). The Tisza mega-unit forms a more than $100,000 \mathrm{~km}^{2}$-large lithosphere fragment that was part of the southern margin of the Variscan Europe. This microplate was separated from Europe during the Jurassic, and then underwent complicated drifting and rotational processes until it occupied its current setting in the Pannonian Basin during the Early Miocene (e.g., Csontos et al., 1992; Csontos and Vörös, 2004; Szederkényi et al., 2013). Predominantly, it is covered by thick Cenozoic sequences, but basement outcrops occur in the Papuk-Krndija Mts (NE Croatia), in the Mecsek and Villány Mts (SE Hungary), and in the Apuseni Mountains (Romania) (Fig. 1). It is widely accepted, based on paleontological and sedimentological evidence (Nagy, 1968; Mader, 1992; Török, 1997, 1998; Haas and Péró, 2004), that much of the Triassic successions of the Tisza mega-unit show similarities with the tripartite Germanic epicontinental sequences.

In the Szeged Basin, the Lower Triassic is represented by gray, red, and lilac continental sandstones (Jakabhegy Sandstone Formation). Lower Anisian "Werfen-type" variegated or red shales are frequently reported. The higher part of the Anisian and the Ladinian is represented by shallow-marine lagoonal dolomites (Bércziné Makk, 1986). These sediments were deposited on a huge ramp system on the southern margin of the European continental plate and the northern shelf of the Tethys (Bleahu et al., 1994; Török, 1998; Haas and Péró, 2004). The early rifting stage during the Middle Triassic caused disintegration of this ramp system and resulted in the opening of incipient oceanic branches of the Neotethys. Differentiation of this huge, mostly dolomitic ramp began in the Late Anisian and resulted in the formation of intrashelf basins and carbonate platforms within the Tisza mega-unit (Bleahu et al., 1994; Konrád, 1998; Haas et al., 1999).

This study focuses on the Late Anisian to Early Ladinian carbonate rocks that are classified as Szeged Dolomite Formation (SDF) in the local lithostratigraphy. It is characterized by a brecciated shallow marine dark gray dolomite sequence with a rather board range of thicknesses $(20-677 \mathrm{~m})$ in complicated structural positions (Bércziné Makk, 1986). Generally, its fossil record is poor but algal fragments, foraminifers composed of Hoyanella, Glomospirella, and Glomospiradominated assemblage, echinoderms, mollusks, and ostracods were reported from some localities (Bércziné Makk, 1986; Szurominé Korecz et al., 2018).

According to several authors (Bércziné Makk, 1986; Garaguly et al., 2017; Szurominé Korecz et al., 2018), most of the examined sediments formed under shallow marine conditions including tidal flat, backreeflagoon, and carbonate sand shoal environments. The dark color of dolomites and the identified fossil assemblage suggest a restricted, anoxic environment and waters of elevated salinity during the deposition. The basin-wide absence of gypsum/anhydrite within the SDF, however, suggests that evaporated sea water did not reach the salinity required for abundant gypsum precipitation (Szurominé Korecz et al., 2018).

Based on textural observations (Garaguly et al., 2017), these sediments were completely dolomitized by either fabric-preserving or fabric-destructive processes. Differences among the observed dolomite fabrics suggest multiple dolomitization episodes. The main dolomitization events produced aphanocrystalline to finely crystalline planar-s dolomite type, that were followed by the formation of porphyrotopic dolomite and pore-filling saddle dolomite (Garaguly et al., 2017). These carbonate rocks serve as good aquifers (Stevanović et al., 2015) and hydrocarbon reservoirs in this region of Hungary with significant hydrocarbon production (Bércziné Makk, 1986; Dank, 1988; Teleki et al., 1994). Nonetheless, detailed geochemical studies dealt with the SDF have not been published yet.

\subsection{Post-Triassic tectonic and magmatic activity}

After the Triassic, a long lasting extensional regime prevailed in the studied area, and the subsidence of the basin continued during the Jurassic and into the Early Cretaceous time (Haas and Péró, 2004). As a result, the studied succession reached the dry gas zone, but it could not suffer considerably greater heating than its present day temperature $\left(142-184^{\circ} \mathrm{C}\right.$ ) in the northern part of the Szeged Basin (Póka et al., 1987).

After the deposition of the Triassic sediments, the most significant compressional tectonic event was the Eoalpine tectonic phase (Austrian and Laramian phases) which created complicated nappe systems (Fig. 3a). These processes resulted in widespread presence of 


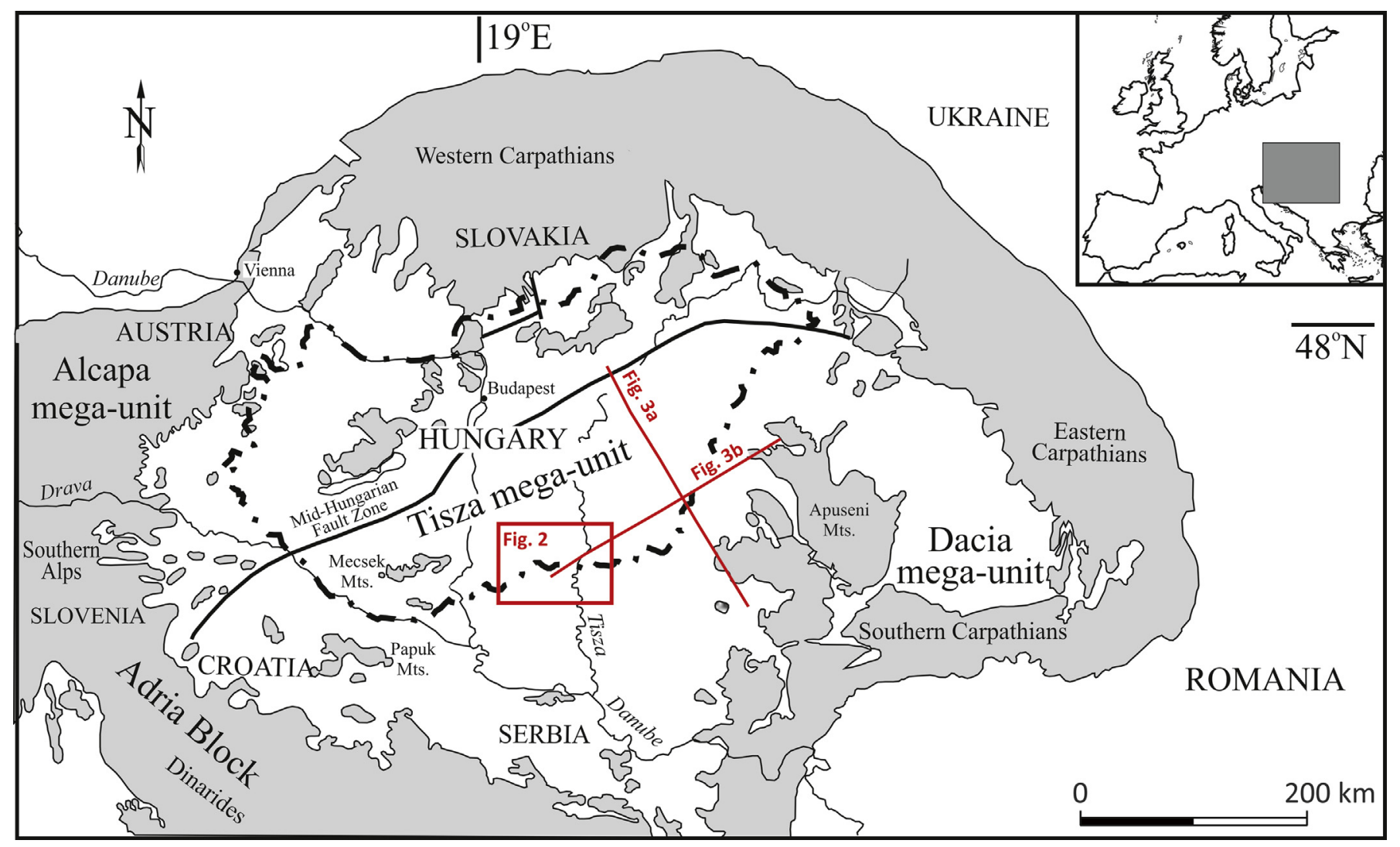

Fig. 1. Geologic framework and major tectonic units of the Carpathian-Pannonian area (modified after Csontos et al., 1992). The gray patches represent orogenic belts and mountains.

subhorizontal, north-northwest-directed thrusts throughout the basement of the Pannonian Basin (e.g., Tari et al., 1999; Csontos and Vörös, 2004; Matenco and Radivojević, 2012; Molnár et al., 2015; Reiser et al., 2016). The locally occurring Late Cretaceous (95-82 Ma) tectonometamorphism was presumably related to these overthrust zones where the Lower to Middle Triassic sediments could be affected by low-grade metamorphism (Árkai et al., 2000; Árkai, 2001).

In the basement of the SE part of the Pannonian Basin, several small subvolcanic intrusions and dykes of granite, granodiorite, and diorite with white mica $\mathrm{K}-\mathrm{Ar}$ ages of 64-75 Ma were encountered (Szederkényi, 2007). They are probably in a close genetic relationship with the so-called 'banatite' magmatism of similar age in the Apuseni Mts. and the South Carpathians (Szederkényi, 1984, 2007; Haas and Péró, 2004; Szederkényi et al., 2013). In the eastern part of the Tisza mega-unit, the 'banatitic' calc-alkaline magmatism was accompanied by the subduction of the Vardar oceanic branch and by the collision of continental blocks during the Cretaceous-Paleocene (e.g., Berza et al., 1998; Merten et al., 2011). Numerous geochronological data from these volcanic and plutonic rocks display ages from 65 to 92 Ma (e.g., Ciobanu et al., 2002; Neubauer, 2002 and references therein).

Small elongated 'banatite' intrusions in the southern part of the Great Hungarian Plain are accompanied by relatively broad (400-600 m), tourmaline-rich muscovite schist aureoles, with an ENE-WSW strike. In some boreholes (Fig. 2) only contact pneumatolytic-hydrothermally altered zones can be found (Szederkényi, 1984, 2007; M. Tóth, 2008; M. Tóth et al., 2017).

Due to the back-arc type extension during the Middle Miocene, metamorphic core complexes were formed by the exhumation of a series of crystalline domes along low-angle normal faults (Tari et al., 1999; Matenco and Radivojević, 2012). During the Badenian, as a progression of this extensional tectonics, horst-graben structures formed along N-S striking normal faults (Fig. 3b).
After the Middle Miocene, intensive subsidence of the basement of the Pannonian Lake resulted in the deposition of a thick $(1.5-4 \mathrm{~km})$ sedimentary succession. As a result of periodic subaquatic eruptions, Late Miocene basaltic rocks are intercalated into the coeval sediments. In the SE Pannonian Basin, most of the basaltic volcanics only subcrop, however, they were encountered in several wells (e.g., Szabó et al., 2016 and references therein). The age of these basaltic lava and pyroclastic rocks was estimated 8-11.6 Ma in the Szeged Basin (Magyar et al., 2004). The crustal thinning caused, contemporaneously with the basaltic volcanism and intensive basin subsidence, a steep increase of the heat flow rate within the Pannonian Basin. During the Neogene extension, the heat flow rate increased from ca. $30 \mathrm{~mW} / \mathrm{m}^{2}$ to $110 \mathrm{~mW} /$ $\mathrm{m}^{2}$ (Dövényi and Horváth, 1988; Lenkey, 1999).

\subsection{Petroleum system}

The Szeged Basin and its surroundings (Algyő, Forráskút, Üllés, Ásotthalom, Szeged fields) is one of the most important hydrocarbonproducing areas in Hungary. Within the local petroleum system, the major source rocks are Middle Miocene marls and carbonates and the Upper Miocene Endrőd Calcareous Marl (e.g., Dank, 1988; Badics and Vető, 2012 and references therein).

The Mesozoic formations overlain by Neogene sediments with significant thickness are mainly overmature, thus the potential Mesozoic source rocks reached the dry-gas zone due to burial and heating caused by thrusting during the Cretaceous (Póka et al., 1987; Árkai et al., 2000). Their hydrocarbon charge was probably lost during the widespread Late Cretaceous-Paleogene uplift and erosion events, as it is general within the Tisza mega-unit (Badics and Vető, 2012 and references therein).

On the other hand, the main seals are Middle to Upper Miocene shale layers in the studied area. Generation of hydrocarbons occurred 


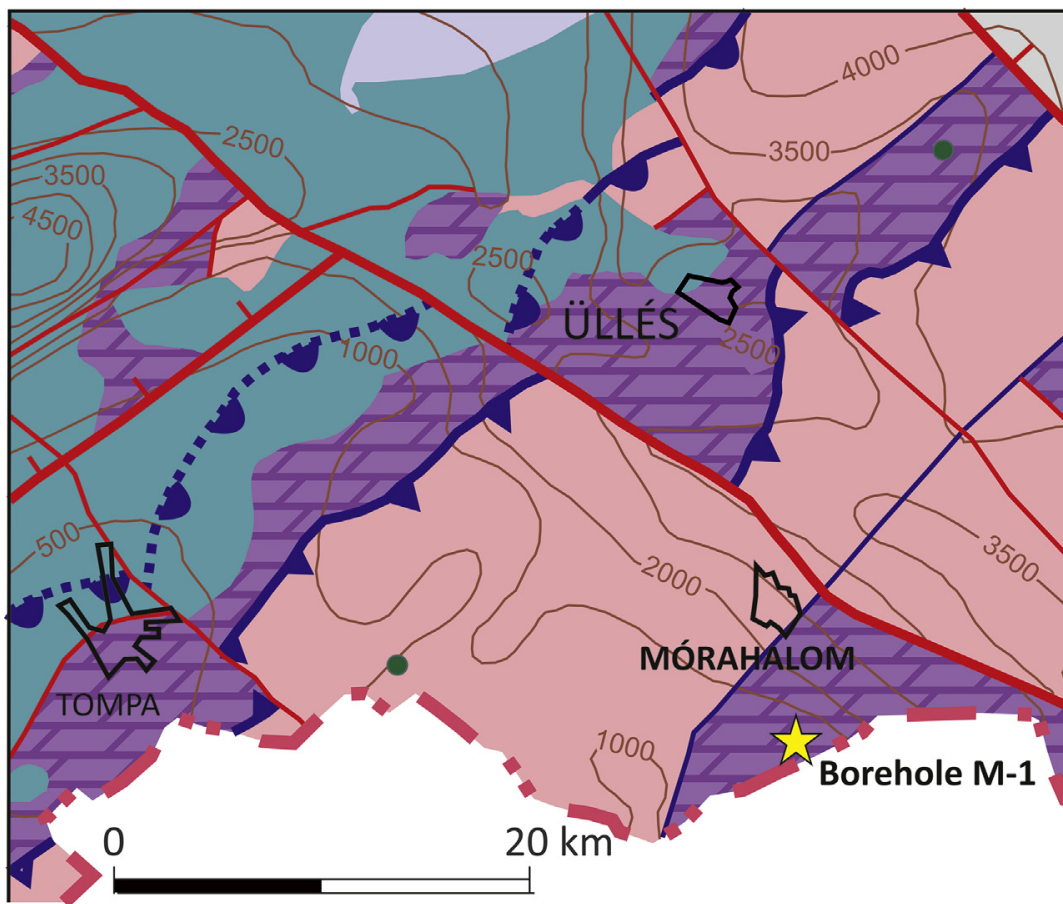

Middle Triassic shallow marine siliciclastic and carbonate formations

Lower Triassic siliciclastic formation of fluvial and delta facies

\section{Mesozoic nappes and overthrusts}

Jurassic and Cretaceous formations

Pre-Mesozoic and metamorphic complexes

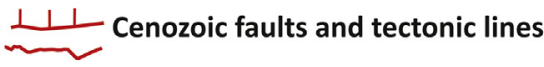

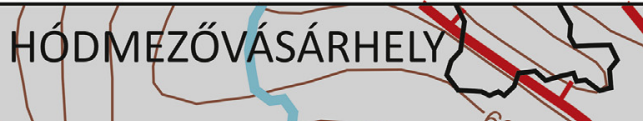
HÓDMEZÖVÁSÁRHELY

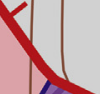

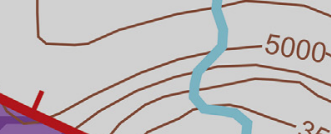

Fig. 2. Generalized geological map of the basement of the Szeged Basin (modified after Haas et al., 2010), showing sampling locality.

from the Late Miocene or Pliocene to present-day, depending on the rate and degree of the tectonically-induced subsidence (e.g., Horváth and Dovenyi, 1988; Badics and Vető, 2012). Throughout the Szeged Basin, anticlinal features (particularly compactional anticlines over uplifted basement blocks), paleogeographic highs, growth faults, and rollover structures are the main trap types in conventional plays (Kókai and Pogácsás, 1991). The reservoir rocks are highly variable (e.g., fractured Variscan metamorphites, Mesozoic sandstones and carbonates, Upper Miocene sandstones and fractured basalts) (see Dank, 1988; Kókai and Pogácsás, 1991; Szabó et al., 2009, 2016).

\section{Samples and methods}

The sampled well $\mathrm{M}-1$ is located on the southern margin of the Szeged Basin (Fig. 2) and was drilled as a hydrocarbon exploration well in 1974. The available 7 borehole core sections from the well $\mathrm{M}-1$ were sampled from the depth interval between 1179 and $1390 \mathrm{~m}$ below sea level and were taken for detailed petrography and geochemical studies. Each sample $(n=11)$ belongs to the SDF and was provided by the MOL Plc.

Micropetrography was done on thin sections of $30 \mu \mathrm{m}$ thickness. In order to distinguish calcite, dolomite, and ferroan variants, the thin sections were stained with alizarin red-S and potassium ferricyanide as described by Dickson (1966). Dolomite texture was described according to the classification scheme of Machel (2004). Fluorescence microscopy was performed using an Olympus BX-41 microscope equipped with a high pressure $\mathrm{Hg}$ lamp and filter sets for blue-violet (400-440 nm) and ultraviolet $(360-370 \mathrm{~nm})$ excitation. Cathodoluminescence (CL) microscopy was carried out by a Reliotron VII type cold CL device
(Department of Mineralogy, Geochemistry and Petrology, University of Szeged) operating at $8 \mathrm{kV}$ and $\sim 600 \mu \mathrm{A}$.

Stable carbon and oxygen isotope analyses were done in the Institute for Geological and Geochemical Research of the Hungarian Academy of Sciences (Budapest). Thirty-five powdered samples were taken for fabric-selective stable isotope analyses using a hand-held dental drill. The dolomite powder was analyzed using the continuous flow technique with the $\mathrm{H}_{3} \mathrm{PO}_{4}$ digestion method (Rosenbaum and Sheppard, 1986; Spötl and Vennemann, 2003). ${ }^{13} \mathrm{C} /{ }^{12} \mathrm{C}$ and ${ }^{18} \mathrm{O} /{ }^{16} \mathrm{O}$ ratios of $\mathrm{CO}_{2}$ generated by acid reaction were measured using a Thermo Finnigan Delta Plus XP continuous flow mass spectrometer. The results are expressed in the standard $\delta$ notation as permil (\%) relative to the Vienna Pee Dee Belemnite (V-PDB) standard. Duplicates of standards and samples were reproduced at better than \pm 0.15 and $\pm 0.1 \%$, for oxygen and carbon isotopes, respectively.

Eight fabric-selected, powdered dolomite samples $(\sim 2 \mathrm{mg})$ were dissolved in $6 \mathrm{M} \mathrm{HCl}$ and, after drying, loaded in $3 \mathrm{M} \mathrm{HNO}_{3}$ onto disposable $1 \mathrm{ml}$ pipette tip extraction columns with a fitted frit and

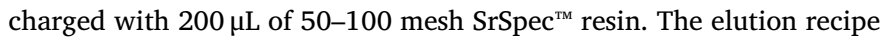
essentially followed that by Horwitz et al. (1992), scaled to our needs, where strontium is eluted/stripped by pure deionized water and then the eluate dried on a hotplate. Strontium samples were then dissolved in $2.5 \mu \mathrm{l}$ of a $\mathrm{Ta}_{2} \mathrm{O}_{5}-\mathrm{H}_{3} \mathrm{PO}_{4}$ - $\mathrm{HF}$ activator solution and directly loaded onto previously outgassed $99.98 \%$ single rhenium filaments. Samples were measured at $1250-1300{ }^{\circ} \mathrm{C}$ in dynamic multi-collection mode on a VG Sector 54 IT mass spectrometer equipped with $8 \mathrm{~F}$ detectors (Department of Geoscience and Natural Resource Management, University of Copenhagen). The ${ }^{86} \mathrm{Sr} /{ }^{88} \mathrm{Sr}$ ratio was corrected to 0.1194 to accommodate for thermal fractionation. Five nanogram loads of the NBS 


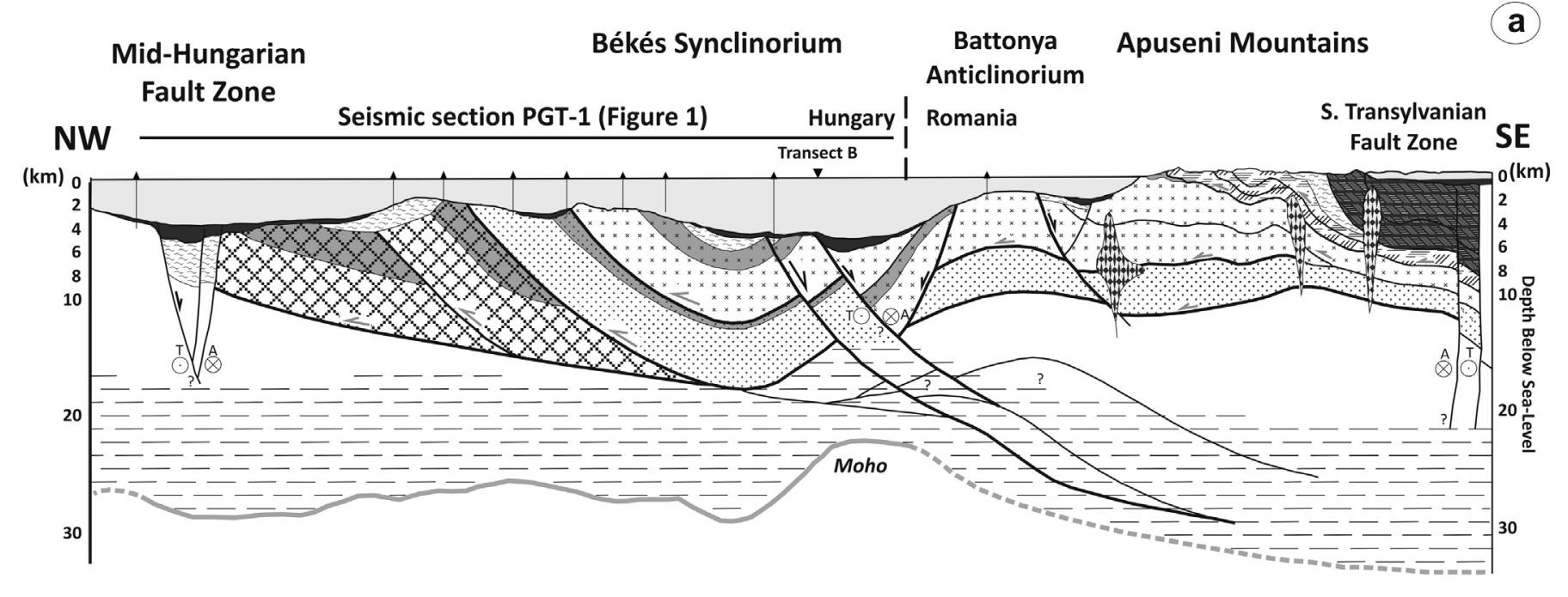

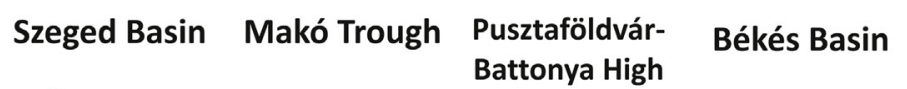

Apuseni Mountains

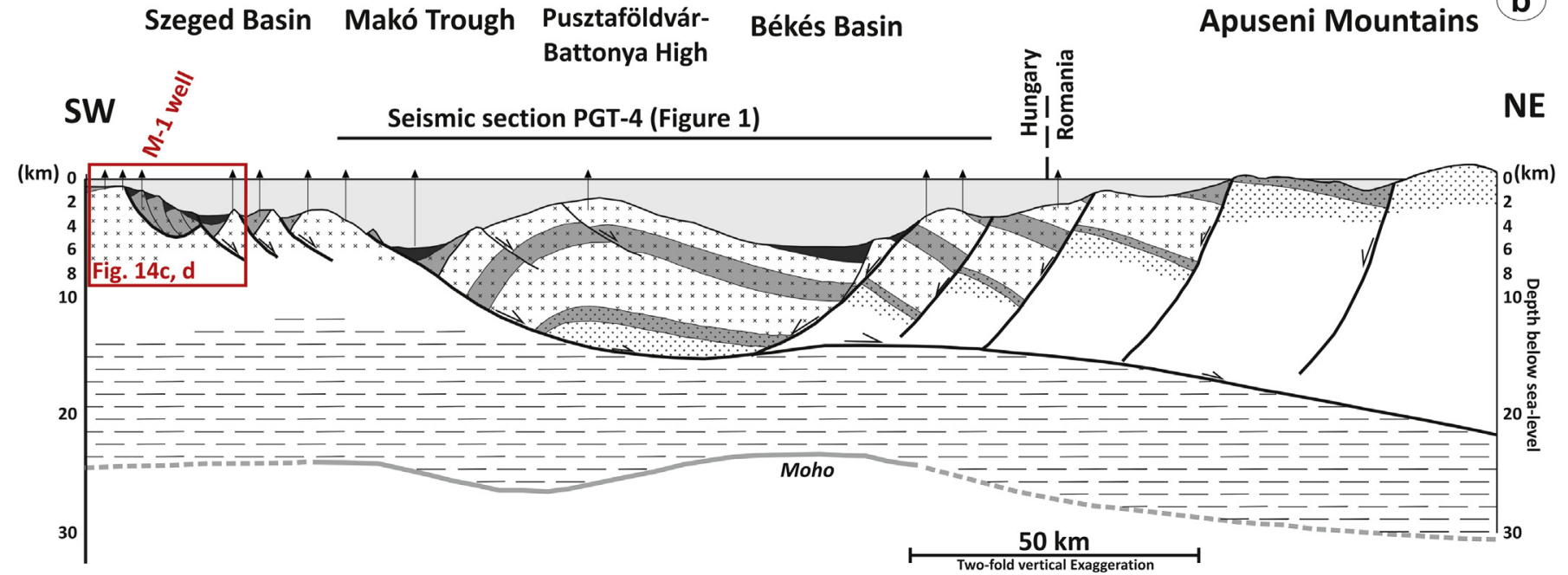

Eoalpine (Cretaceous) basement and tertiary basins
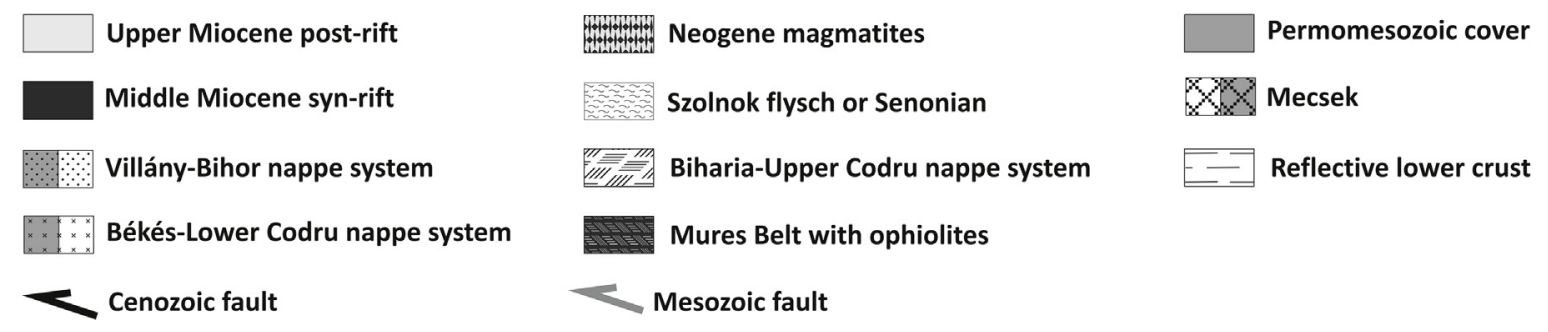

Fig. 3. Regional transects across the SE Pannonian Basin (modified after Tari et al., 1999). For location see Fig. 1.

$987 \mathrm{Sr}$ standard gave ${ }^{87} \mathrm{Sr} /{ }^{86} \mathrm{Sr}=0.710239 \pm 0.000010(\mathrm{n}=5,2 \sigma)$. All samples were normalized to ${ }^{87} \mathrm{Sr} /{ }^{86} \mathrm{Sr}=0.710245$ for international comparability.

For fluid inclusion (FI) study, representative samples containing saddle dolomite and quartz phases were selected. Six double-polished thick sections $(50-80 \mu \mathrm{m})$ prepared following the instructions of Shepherd et al. (1985) were studied for FI petrography, microthermometry and Raman spectroscopy. Microthermomety began with the mapping of thick sections for fluid inclusions, and the FI assemblages were characterized following the criteria of Goldstein and Reynolds (1994). Fluid inclusions that show petrographic evidence of having undergone necking down were excluded from measurements. Initial heating of samples was carried out to avoid the stretching of inclusions caused by freezing of the liquid phase. In order to accurate documentation of phase changes, stepwise $1{ }^{\circ} \mathrm{C}$ heating was applied, checking all studied inclusions between steps. Microthermometry was carried out using a Linkam THMSG-600 heating-freezing stage mounted on an Olympus BX-41 microscope at the Department of Mineralogy, Geochemistry and Petrology, University of Szeged. Synthetic FIs were used for calibration at $-56.6^{\circ} \mathrm{C}, 0.0^{\circ} \mathrm{C}$ and $374.0^{\circ} \mathrm{C}$. Temperatures of homogenization $\left(\mathrm{T}_{\mathrm{h}}\right)$ and final melting of ice $\left(\mathrm{T}_{\mathrm{m}}\right.$ (ice)) have standard errors of $\pm 1{ }^{\circ} \mathrm{C}\left(\mathrm{T}>100{ }^{\circ} \mathrm{C}\right)$ and $\pm 0.2^{\circ} \mathrm{C}\left(\mathrm{T}<0{ }^{\circ} \mathrm{C}\right)$, respectively.

The $\mathrm{T}_{\mathrm{h}}$ and $\mathrm{T}_{\mathrm{m}}$ (ice) values were usually determined by the cycling method (Goldstein and Reynolds, 1994). Salinity values of the aqueous inclusions were calculated from the final ice-melting temperatures and reported in mass percent (mass\%) of $\mathrm{NaCl}$ equivalent (Bodnar, 1993). 
If the presence of dissolved methane can be assumed in the inclusions, the calculated salinity values need to be reduced to account for the minor effect of dissolved methane gas, or for the strong effect of methane hydrate clathrate, which tends to concentrate salts in the residual aqueous liquid. In the present study, these corrections cannot be made quantitatively, because the concentrations of the methane in the aqueous inclusions were not determined. The reported salinity values therefore represent maximum values.

Raman microspectroscopy analyses were done on 41 fluid inclusions hosted in Cd-2 dolomite and 18 inclusions hosted in quartz. A confocal Thermo Scientific DXR Raman Microscope (Department of Mineralogy, Geochemistry and Petrology, University of Szeged) was used to detect volatile phases in the FIs. All measurements were carried out with a laser wavelength of $532 \mathrm{~nm}$ and $1-10 \mathrm{~mW}$ laser power using a $100 \times$ objective lens. The spectral resolution of the instrument is around $2 \mathrm{~cm}^{-1}$ and the spatial resolution is about $3-4 \mu \mathrm{m}^{3}$. For qualitative evaluation, resulting Raman shifts were compared with the Raman database provided by Frezzotti et al. (2012).

Hydrogen isotope composition of fluid inclusion-hosted $\mathrm{H}_{2} \mathrm{O}$ in separated portions of vein-filling $\mathrm{Cd}-2$ saddle dolomite (M-1/10/1 sample) was determined by vacuum crushing at the Institute for Geological and Geochemical Research of the Hungarian Academy of Sciences (Budapest) following the method described by Czuppon et al. (2014) and Demény et al. (2016). Separated chips of 2-3 g (3-5 mm in diameter) were placed in stainless steel tubes, pumped to vacuum, and then crushed using a hydraulic press. The concentration and $\mathrm{D} / \mathrm{H}$ ratios of the released and vacuum distilled $\mathrm{H}_{2} \mathrm{O}$ were determined by a liquid water isotope analyzer (LWIA) manufactured by Los Gatos Research Ltd (model LWIA-24d). Stable isotope data for hydrogen are expressed in the standard $\delta$ notation as permil (\%o) relative to standard mean ocean water (V-SMOW). The precision during repeated measurements was better than $2 \%$ for $\delta \mathrm{D}$ values. The simultaneously measured $\delta^{18} \mathrm{O}$ data were not interpreted because of high probability of oxygen isotope exchange between the host mineral and inclusion hosted water after trapping and during cooling of the host mineral. This process may shift the original oxygen isotope composition of the inclusion water to more negative values while the hydrogen isotope composition remains intact (e.g., Naden et al., 2003; Demény et al., 2016).

\section{Petrography}

The most important petrographic features of the studied SDF samples are summarized in Table 1. Carbonate staining reveals that most of the examined samples consist of non-ferroan dolomite. Only a few porefilling carbonate crystals and two host rock samples show pale mauve or bluish color after staining indicating the presence of minor amount of ferroan calcite. In the upper part of the studied section, fabric-preserving or fabric-selective dolomite is predominant, while samples from the middle to lower parts of the borehole $M-1$ were mainly subject to fabric-destructive dolomitization (Table 1).

Based on petrography, three types of matrix dolomites (Md-1 to Md3 ) and three types of cement dolomites (Cd-1 to Cd-3) are recognized. Types of the matrix dolomites are the followings: (1) aphanocrystalline to medium crystalline fabric-preserving dolomite (Md-1), (2) very finely to finely crystalline fabric-destructive planar-s dolomite (Md-2), and (3) medium to coarsely crystalline fabric-destructive, porphyrotopic, and transitional (planar-s to nonplanar-a) dolomite (Md-3). As far as the cement dolomites are concerned the following types are distinguished: (1) medium to coarsely crystalline planar-s dolomite (Cd1); (2) coarsely crystalline nonplanar-a saddle dolomite (Cd-2), and (3) finely crystalline bituminous dolomite (Cd-3). Postdating the main dolomitization events, sets of late stage calcite (Cal) and quartz (Qtz) cement crystals, and stylolites were formed. Additionally, the distinct dolomite fabrics are characterized by different porosity types that are also described below.

All of the studied rock specimens were affected by various degrees of brittle deformation and dissolution processes (Fig. 4a and b). Most of the samples contain relatively small amount of hairline cracks and fractures cemented by white sparry dolomite crystals. Subordinately, brecciated samples are also present. Using the non-genetic classification of breccias described by Woodcock and Mort (2008), two samples (M-1/10/1; M-1/13/1) were classified as crackle (Fig. 4a) and mosaic breccias that contain $70-80 \%$ of cement with moderate clast rotation with respect to each other. Polished and striated fault surfaces were also observed in these monomictic breccias from the lower part of the studied section.

\subsection{Matrix dolomites}

\subsubsection{Md-1 dolomite}

Macroscopically, this type of dolomite is generally gray colored with darker and lighter patches (Fig. 4b). The fabric-preserving dolomite textures described here can be classified into stromatolitic dolomites, intraformational breccias and dolograinstones. Based on the micropetrographic observations, the dolomite crystal size varies according to the grain size of the precursor carbonate phase, such that micritic grains

Table 1

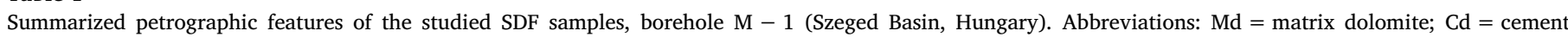
dolomite; Cal = calcite; Qtz = quartz.

\begin{tabular}{|c|c|c|c|c|c|c|c|}
\hline \multirow[t]{2}{*}{ Sample ID } & \multirow[t]{2}{*}{ Depth below sea level (m) } & \multicolumn{2}{|l|}{ Fabric preservation } & \multirow[t]{2}{*}{ Lithofacies and preserved microfabric elements } & \multicolumn{2}{|c|}{ Matrix Dolomite } & \multirow[t]{2}{*}{ Cement types } \\
\hline & & Fabric-preserving & Fabric-destructive & & Major & Minor & \\
\hline $\mathrm{M}-1 / 4 / 1$ & 1179-1196 & $\mathrm{X}$ & - & Stromatolite (fenestral laminated microbialite) & Md-1 & - & Cd-2, Cd-3, Cal \\
\hline $\mathrm{M}-1 / 4 / 2$ & & $\mathrm{X}$ & - & & Md-1 & - & $\mathrm{Cd}-2, \mathrm{Cd}-3$ \\
\hline $\mathrm{M}-1 / 4 / 3$ & & $\mathrm{X}$ & - & Stromatolite with coated intraclasts, bioclasts & Md-1 & - & $\mathrm{Cd}-2, \mathrm{Cd}-3$ \\
\hline $\mathrm{M}-1 / 5 / 1$ & $1196.5-1201.5$ & $\mathrm{X}$ & $\mathrm{X}$ & $\begin{array}{l}\text { Intraformational breccia with micrite-coated } \\
\text { intraclasts and peloids }\end{array}$ & $\begin{array}{l}\text { Md-1, Md- } \\
2\end{array}$ & Md-3 & Cd-2, Cd-3, Cal \\
\hline $\mathrm{M}-1 / 5 / 2$ & & - & $\mathrm{X}$ & Bioclast ghosts & $\begin{array}{l}\text { Md-2, Md- } \\
3\end{array}$ & - & $\mathrm{Cd}-2, \mathrm{Cd}-3$ \\
\hline $\mathrm{M}-1 / 6 / 1$ & $1212.5-1217.5$ & - & $\mathrm{X}$ & - & Md-3 & Md-2 & Cd-2, Cal \\
\hline $\mathrm{M}-1 / 7 / 1$ & $1223-1230.5$ & - & $\mathrm{X}$ & Bioclast ghosts & $\begin{array}{l}\text { Md-2, Md- } \\
3\end{array}$ & - & $\mathrm{Cd}-2, \mathrm{Cd}-3$ \\
\hline $\mathrm{M}-1 / 9 / 1$ & $1262-1263.5$ & $\mathrm{X}$ & $\mathrm{X}$ & Bioclastic grainstone-packstone & $\begin{array}{l}\text { Md-1, Md- } \\
3\end{array}$ & - & $\mathrm{Cd}-2$ \\
\hline $\mathrm{M}-1 / 10 / 1$ & $1275-1284$ & - & $\mathrm{X}$ & - & Md-2 & Md-3 & $\begin{array}{l}\text { Cd-1, Cd-2, Cd-3, } \\
\text { Qtz }\end{array}$ \\
\hline $\mathrm{M}-1 / 10 / 2$ & & - & $\mathrm{X}$ & - & Md-2 & Md-3 & Cd-3 \\
\hline $\mathrm{M}-1 / 13 / 1$ & $1390-1390.5$ & - & $\mathrm{X}$ & - & Md-2 & Md-3 & $\begin{array}{l}\text { Cd-1, Cd-2, Cd-3, } \\
\text { Cal }\end{array}$ \\
\hline
\end{tabular}



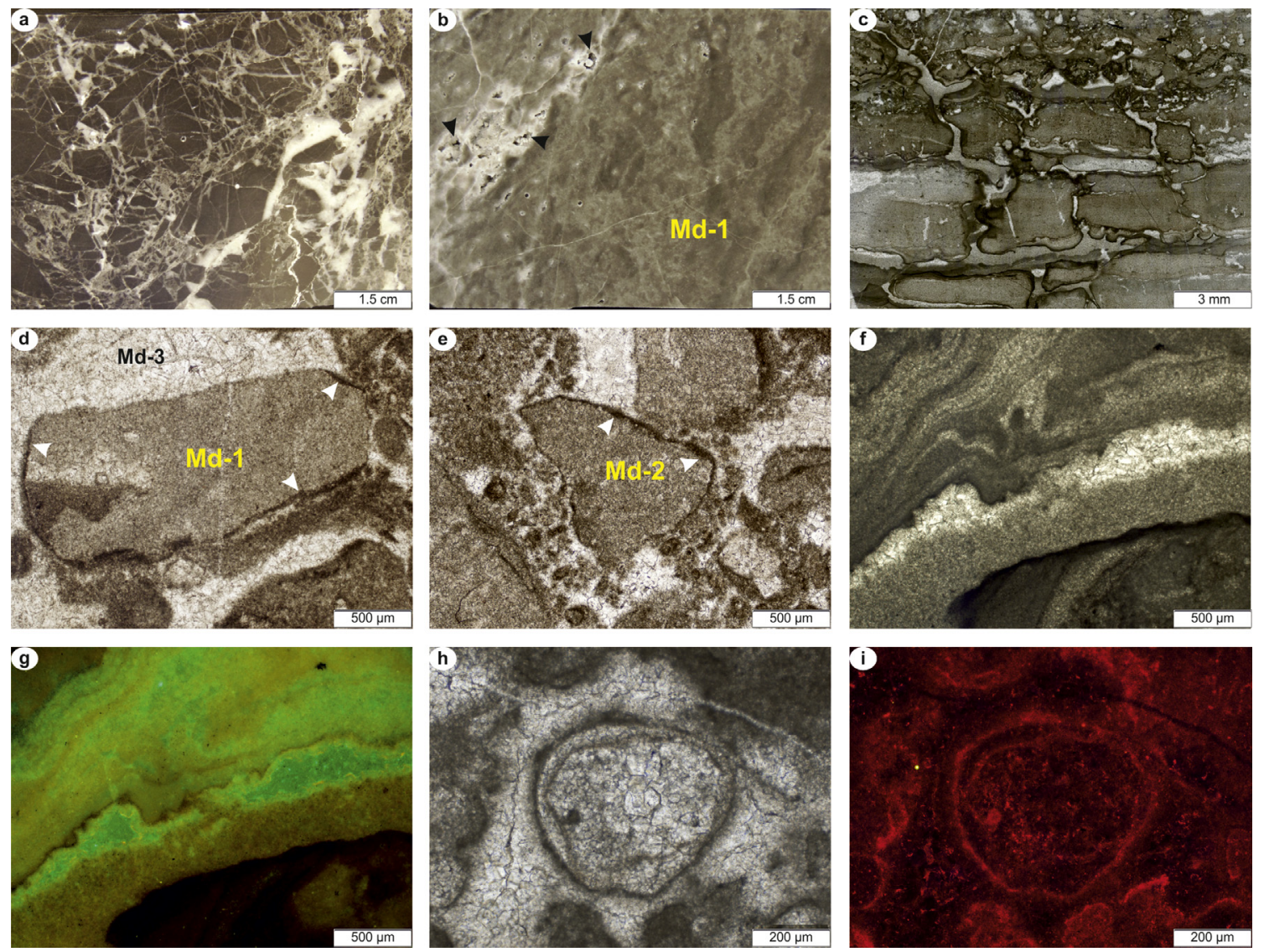

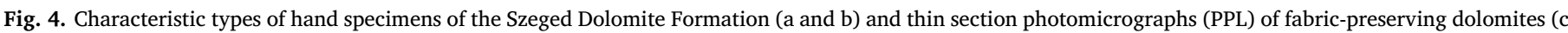

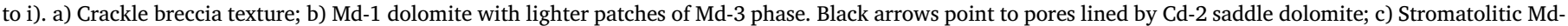

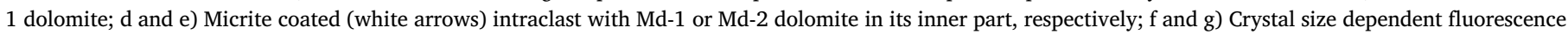
of stromatolitic Md-1 dolomite; h and i) Crystal size dependent CL of Md-1 dolomite.

are replaced with aphanocrystalline to finely crystalline dolomite, whereas medium crystalline marine cements are replaced with medium crystalline dolomite.

Microbialite textures in stromatolites are generally composed of thin, dark, micritic laminae alternating with light-colored laminae of finely to medium crystalline dolomite (Fig. 4c) and often contain irregular fenestral voids. The grains are mainly bioclasts (crinoid skeletons, fragments of bivalve shells), oncoids, peloids, and intraclasts. The latter grains are often coated with later stage dolomicrite and their inner part are alternately comprised of Md-1 and Md-2 dolomites (Fig. 4d and e).

Fluorescence microscopy on thin sections shows that the fabricpreserving dolomites have yellowish-green fluorescence with a crystal size-dependent intensity, i.e., the zones characterized by larger crystals display more intense fluorescence (Fig. $4 \mathrm{f}$ and g). Under CL microscope, the aphanocrystalline to finely crystalline dolomites display dull orange-red luminescence, while the coarser crystalline dolomites are very dull or non-luminescent (Fig. 4h and i).

\subsection{2. $M d-2$ dolomite}

The Md-2 dolomite is dark gray in hand specimens and has completely obliterated precursor sedimentary textures, only few echinoderm fragments and ghost structures after bioclasts are found. This type of dolomite displays mainly a planar texture composed of very finely to finely crystalline subhedral crystals, which are generally cloudy or have cloudy centers and clear rims (Fig. 5a). Crystal size distribution is relatively unimodal, ranging from 10 to $60 \mu \mathrm{m}$ and dolomite crystals exhibit sharp extinction under crossed polarized light (XPL). This type of dolomite is non-fluorescent under epifluorescence microscope and has no luminescence and/or dull red color under CL. Intercrystalline pore spaces are generally occluded by opaque materials such as bitumen (or pyrobitumen) and pyrite (Fig. 5a).

\subsubsection{Md-3 dolomite}

This type of dolomite is light gray in hand samples and generally forms pockets and patches within the Md-1 or Md-2 dolomites (Fig. 5b and c). Microscopically, it shows two different textural appearances: (1) euhedral dolomite crystals floating in the host matrix of Md-1 or Md-2 dolomite (Fig. 5d), and (2) cm-sized patches of tightly packed subhedral to anhedral dolomite crystals (Fig. 5e). The transition between the aforementioned two types is gradual. The dolomite crystals are generally inequigranular ranging from 100 to $1000 \mu \mathrm{m}$ and the crystal size increases towards the central part of the patches. The Md-3 dolomite generally shows sharp extinction under XPL, but the largest anhedral crystals frequently exhibit a weak undulatory extinction. Under CL, dolomite crystals show blotchy, dull or very dull red luminescence and have slight green fluorescence under violet-blue excitation.

The Md-3 often occurs as a recrystallization product of the Md-1 or Md-2 suggested by the presence of non-recrystallized relicts (Fig. $5 \mathrm{f}$ and g), mosaic texture (Fig. 5e), and blotchy luminescence. The boundaries are commonly sharp between the patches of Md-3 dolomite and the postdated dolomites (Fig. 5h), but gradual transitions are also observed.

\subsection{Cement dolomites}

\subsubsection{Cd-1 dolomite}

The Cd-1 dolomite cement fills fractures, and cavities within the brecciated samples (Table 1). This type of dolomite is generally characterized by mosaics of medium to coarsely crystalline planar-s 

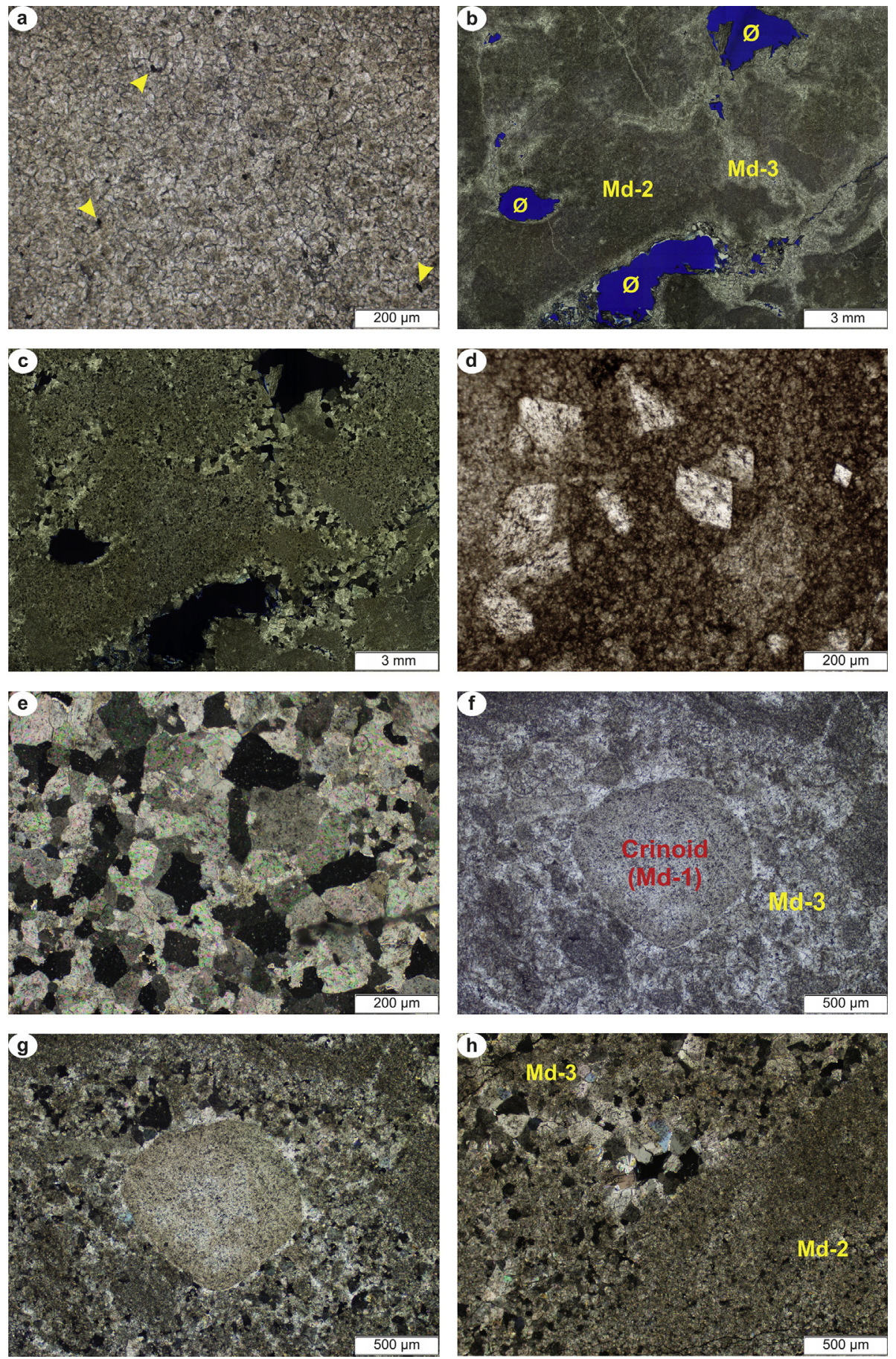

Fig. 5. Thin section photomicrographs of fabric-destructive dolomite textures. a) Very finely to finely crystalline planar-s type Md-1 dolomite. Note pyrite in intercrystalline pores (arrows), PPL; b) and c) Pore- and fracture-related patches of Md-3 dolomite, PPL and XPL; d) Medium-sized porphyrotopic Md-3 dolomite crystals float within a very finely crystalline dolomite. e) Tightly packed planar-s to nonplanar-a Md-3 dolomite with mosaic recrystallization texture, XPL. f) and g) Remnant of an echinoderm skeleton surrounded by Md-3 dolomite, PPL and XPL. h) Sharp boundary between Md-2 and Md-3 dolomites, XPL.

dolomite (Fig. 6a), which has straight and rarely curved intercrystalline boundaries. These limpid crystals show very dull homogenous luminescence under CL and bright green fluorescence under epifluorescence microscope (Fig. 6b). These dolomite veins are commonly cross-cut by later stage cement phases (Cd-2, Cd-3, and Cal) and their intercrystalline porosity is occluded.

\subsubsection{Cd-2 dolomite}

The Cd-2 dolomite cement has milky white color in hand specimen, ranging from $250 \mu \mathrm{m}$ to $2 \mathrm{~mm}$ in crystal size, completely or partially filling the cracks and cavities of the host dolomite. The crystals commonly have curved faces (Fig. 6c) and display undulose extinction under XPL, thus they can be defined as saddle dolomite. Under CL microscope, saddle dolomite crystals exhibit marked zonation defined by alternating dark red and bright red bands (Fig. $6 \mathrm{~d}$ and e). The brighter bands are generally connected to inclusion-rich zones. Except the brecciated samples, Cd-2 dolomite mostly occurs as the initial generation of cements. Saddle dolomite crystals generally become coarser towards the pore center, showing a drusy habit. The residual pore spaces are commonly open or occluded subordinately by later quartz or calcite cement crystals. 

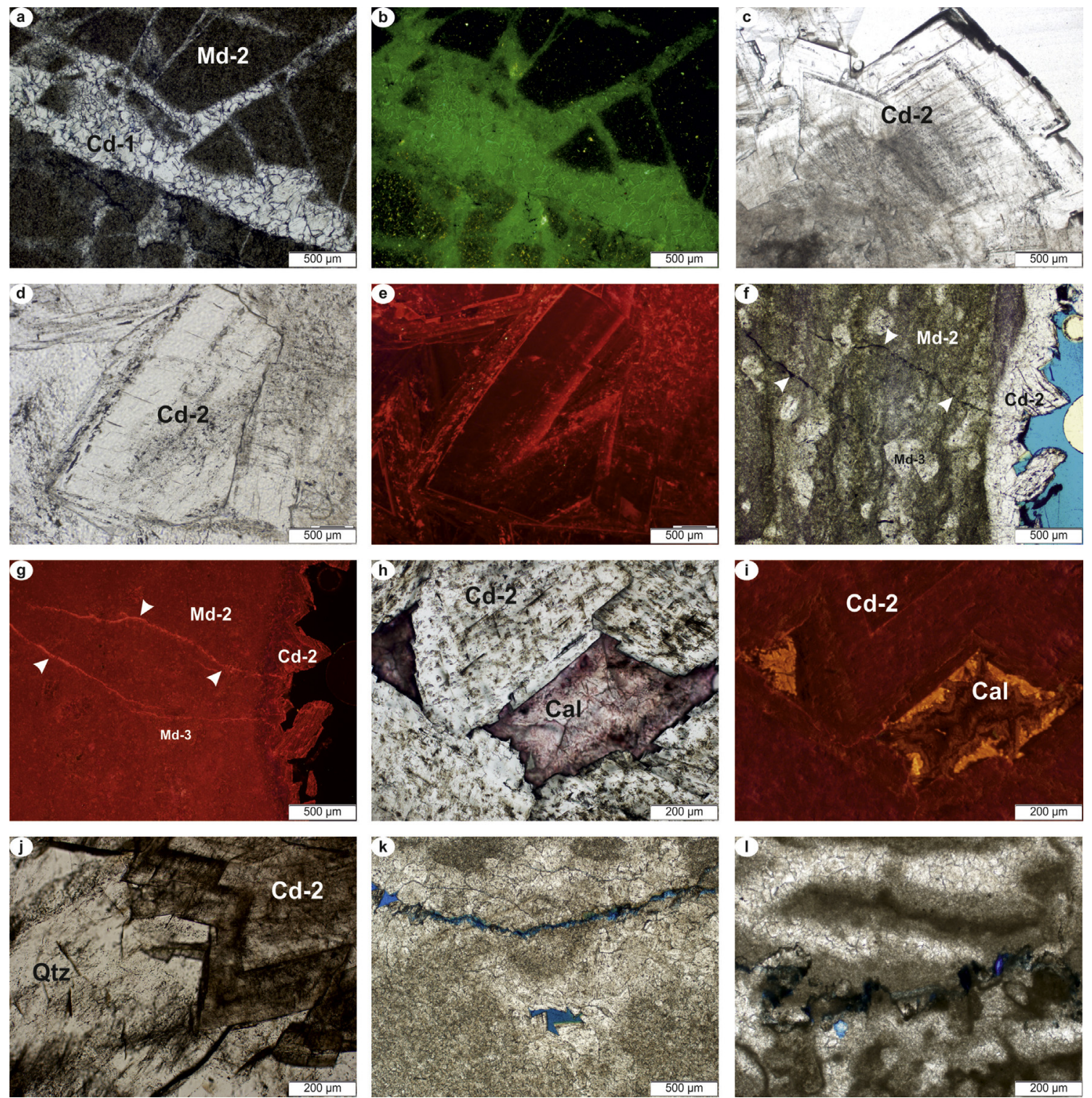

Fig. 6. Thin section photomicrographs of fracture- and pore-filling minerals.

a) and b) Cd-1 dolomite cement within brecciated Md-2 matrix dolomite, PPL and fluorescent micrographs; c-e) Zoned Cd-2 saddle dolomite with curved crystal faces, PPL and CL; f) and g) Distinct types of matrix and cement dolomites intersected by late stage Cd-3 bituminous dolomite (white arrows), PPL and CL; h) and i) Intercrystalline porosity occluded by ferroan calcite, PPL and CL; j) Cd-2 saddle dolomite crystals enveloped by quartz; k) Open fracture and intercrystalline porosity (blue-epoxy impregnated); 1) Microstylolite with blue-epoxy impregnated microporosity. (For interpretation of the references to color in this figure legend, the reader is referred to the Web version of this article.)

\subsubsection{Cd-3 dolomite}

This type of dolomite fills hairline cracks that commonly intersect all matrix dolomite and cement phases (Fig. $6 \mathrm{f}$ and g). It consists of finely crystalline dolomite that is followed by intercrystalline opaque, mainly amorphous materials (solid bitumen and pyrite). This type of dolomite displays bright red luminescence under CL. Epifluorescence microscopy reveals that both $\mathrm{Cd}-3$ dolomite and bitumen have yellowish-green fluorescence.

\subsection{Calcite and quartz (Cal and Qtz)}

There are very minor amount of calcite and quartz cements that occlude partly the remaining porosity which both postdate the Cd-2 saddle dolomite. The space-filling ferroan calcite occurs as millimetersized massive crystals and contacts with Cd-2 saddle dolomite along corroded crystal faces (Fig. 6h). These calcite crystals display greenishwhite fluorescence under violet-blue light and exhibit bright orange to non-luminescence zonation under CL (Fig. 6i). The space-filling quartz cement was observed only in a brecciated sample (M-1/10/1) and it occludes the intercrystalline porosity of Cd-2 saddle dolomite. It occurs as blocky crystals with well-defined boundaries and rare solid dolomite inclusions (Fig. 6j). Quartz crystals are non-luminescent and nonfluorescent under CL and epifluorescence microscopes.

\subsection{Characteristics of pores}

The types of pores in the studied rocks are mainly secondary dissolution pores, intercrystalline pores, open fractures as well as open microstylolites. The principal pore space is given by irregularly shaped cavities that are commonly millimeter to centimeter in size and lined by Cd-2 saddle dolomite (Figs. $4 \mathrm{~b}$ and $5 \mathrm{~b}$ and $\mathrm{c}$ ). The intercrystalline pores between crystals of Md-3 and Cd-2 dolomites are generally polygonal and represent a minor amount of the total porosity (Fig. 6k). Relatively thin, open fractures are subordinately present in each sample and 
Table 2

Stable isotope data $\left(\delta^{13} \mathrm{C}, \delta^{18} \mathrm{O}\right.$, and $\left.{ }^{87} \mathrm{Sr} /{ }^{86} \mathrm{Sr}\right)$ of different types of the SDF dolomite samples, borehole M - 1 (Szeged Basin, Hungary).

\begin{tabular}{|c|c|c|c|c|}
\hline \multirow[t]{2}{*}{ Sample ID } & \multirow{2}{*}{$\begin{array}{l}\text { Measured dolomite phase } \\
\text { (subsamples) }\end{array}$} & \multicolumn{2}{|c|}{ V-PDB } & \multirow[t]{2}{*}{${ }^{87} \mathrm{Sr} /{ }^{86} \mathrm{Sr}( \pm \sigma)$} \\
\hline & & $\delta^{13} \mathrm{C}$ & $\delta^{18} \mathrm{O}$ & \\
\hline $\mathrm{M}-1 / 4 / 1$ & Md-1 & 1.13 & -2.79 & \\
\hline $\mathrm{M}-1 / 4 / 1$ & Md-1 & 1.50 & -2.57 & $0.707831 \pm 000006$ \\
\hline$M-1 / 4 / 1$ & Cd-2 & 1.41 & -6.84 & $0.709187 \pm 000006$ \\
\hline $\mathrm{M}-1 / 4 / 2$ & Md-1 & 1.41 & -2.96 & \\
\hline $\mathrm{M}-1 / 4 / 2$ & Md-1 & 1.32 & -2.26 & \\
\hline $\mathrm{M}-1 / 4 / 2$ & Cd-2 & 1.46 & -6.34 & \\
\hline $\mathrm{M}-1 / 4 / 3$ & Md-1 & 1.27 & -2.15 & \\
\hline $\mathrm{M}-1 / 4 / 3$ & Md-1 & 1.26 & -1.81 & \\
\hline $\mathrm{M}-1 / 5 / 1$ & Md-1 & 1.21 & -1.96 & $0.707896 \pm 000004$ \\
\hline $\mathrm{M}-1 / 5 / 1$ & Md-1 & 1.33 & -2.43 & \\
\hline $\mathrm{M}-1 / 5 / 1$ & $\mathrm{Cd}-2$ & 1.20 & -7.87 & $0.708845 \pm 000008$ \\
\hline $\mathrm{M}-1 / 5 / 1$ & $\mathrm{Cd}-2$ & 1.47 & -7.11 & \\
\hline $\mathrm{M}-1 / 5 / 2$ & Mixture of Md-2 and Md-3 & 1.38 & -4.02 & \\
\hline $\mathrm{M}-1 / 5 / 2$ & Md-2 & 1.40 & -2.45 & \\
\hline $\mathrm{M}-1 / 5 / 2$ & $\mathrm{Cd}-2$ & 1.23 & -8.01 & \\
\hline $\mathrm{M}-1 / 6 / 1$ & Mixture of Md-2 and Md-3 & 1.63 & -3.66 & \\
\hline$M-1 / 6 / 1$ & $\mathrm{Cd}-2$ & 0.81 & -8.21 & \\
\hline $\mathrm{M}-1 / 6 / 1$ & $\mathrm{Cd}-2$ & 0.55 & -9.12 & \\
\hline $\mathrm{M}-1 / 7 / 1$ & Md-2 & 1.46 & -2.14 & \\
\hline $\mathrm{M}-1 / 7 / 1$ & Md-2 & 1.61 & -1.69 & $0.707791 \pm 000008$ \\
\hline $\mathrm{M}-1 / 7 / 1$ & $\mathrm{Cd}-2$ & 1.59 & -6.95 & \\
\hline $\mathrm{M}-1 / 7 / 1$ & $\mathrm{Cd}-2$ & 1.22 & -7.65 & $0.708314 \pm 000006$ \\
\hline $\mathrm{M}-1 / 9 / 1$ & Mixture of Md- 1 and Md- 3 & 1.70 & -4.24 & \\
\hline$M-1 / 9 / 1$ & Mixture of Md- 1 and Md-3 & 1.49 & -4.78 & \\
\hline $\mathrm{M}-1 / 9 / 1$ & $\mathrm{Cd}-2$ & 1.84 & -7.90 & \\
\hline $\mathrm{M}-1 / 10 / 1$ & Md-2 & 1.43 & -3.28 & $0.708313 \pm 000008$ \\
\hline $\mathrm{M}-1 / 10 / 1$ & Cd-2 & 0.77 & -9.24 & $0.709674 \pm 000006$ \\
\hline $\mathrm{M}-1 / 10 / 1$ & $\mathrm{Cd}-2$ & 1.73 & -7.61 & \\
\hline $\mathrm{M}-1 / 10 / 1$ & $\mathrm{Cd}-2$ & 1.58 & -8.42 & \\
\hline $\mathrm{M}-1 / 10 / 1$ & $\mathrm{Cd}-2$ & 1.58 & -7.75 & \\
\hline $\mathrm{M}-1 / 10 / 2$ & Md-2 & 1.41 & -4.18 & \\
\hline $\mathrm{M}-1 / 13 / 1$ & Md-2 & 1.57 & -3.86 & \\
\hline $\mathrm{M}-1 / 13 / 1$ & Mixture of Md-2 and Md-3 & 1.39 & -4.19 & \\
\hline $\mathrm{M}-1 / 13 / 1$ & Cd-1 & 1.62 & -4.14 & \\
\hline $\mathrm{M}-1 / 13 / 1$ & Cd-1 & 1.40 & -4.85 & \\
\hline
\end{tabular}

connect cavities (Fig. 6k). Microstylolites are observed in most of the studied samples and they mainly contain amorphous opaque materials, however, in a few samples reopened microstylolites occurred representing a subordinate amount of porosity (Fig. 61).

\section{Carbon, oxygen, and strontium isotopes}

The carbon, oxygen and strontium isotopic compositions of the SDF samples are listed in Table 2 and plotted in Figs. 7 and 8a. For comparison, the ${ }^{87} \mathrm{Sr} /{ }^{86} \mathrm{Sr}$ ratios, $\delta^{13} \mathrm{C}$ and $\delta^{18} \mathrm{O}$ range of calcites precipitated in equilibrium with Middle Triassic seawater (Korte et al., 2003, 2005), as well as the estimated isotopic composition of coeval marine dolomites (cf. Major et al., 1992) are also plotted.

The $\delta^{18} \mathrm{O}_{\mathrm{V}-\mathrm{PDB}}$ and $\delta^{13} \mathrm{C}_{\mathrm{V}-\mathrm{PDB}}$ data of Md-1 dolomite range from -1.81 to $-2.96 \%$ and +1.50 to $+1.13 \%$, respectively. $\mathrm{The}{ }^{87} \mathrm{Sr} /{ }^{86} \mathrm{Sr}$ values for this type of dolomite vary between 0.707896 and 0.707831 . The Md-2 dolomite samples have $\delta^{18} \mathrm{O}_{\mathrm{V}-\mathrm{PDB}}$ values of -1.69 to $-4.18 \%$ and $\delta^{13} \mathrm{C}_{\mathrm{V} \text {-PDB }}$ values of +1.61 to $+1.40 \%$. Their Sr isotope ratios vary from 0.708313 to 0.707791 . Sampling of pure Md-3 dolomite was not accomplishable because of the porphyrotopic texture and the relicts of the earlier dolomite phases. Thus, due to the high probability of mixing between distinct phases, measured isotopic data could be interpreted as mixtures of Md-3 and Md-1 or Md-2 dolomites of unknown proportion, and provide only indirect information about the initial compositions. These composite samples display $\delta^{18} \mathrm{O}_{\mathrm{V}-\mathrm{PDB}}$ values from -3.66 to $-4.85 \%$ and $\delta^{13} \mathrm{C}_{\mathrm{V} \text {-PDB }}$ values from +1.70 to $+1.38 \%$.

The $\delta^{18} \mathrm{O}_{\mathrm{V}-\mathrm{PDB}}$ and $\delta^{13} \mathrm{C}_{\mathrm{V}-\mathrm{PDB}}$ values for Cd-1 dolomite vary from -4.14 to $-4.85 \%$ and from +1.62 to $+1.40 \%$, respectively. On the other hand, the Cd-2 dolomite samples display $\delta^{18} \mathrm{O}_{\mathrm{V}-\mathrm{PDB}}$ values from -6.34 to $-9.24 \%$, $\delta^{13} \mathrm{C}_{\mathrm{V} \text {-PDB }}$ values from +1.84 to $+0.55 \%$, and $\mathrm{Sr}$ isotope ratios from 0.709674 to 0.708314 . In the case of Cd-2 dolomites, a negative shift can be observed in $\delta^{18} \mathrm{O}$ values towards higher depths (Fig. 8a). Veins of Cd-3 dolomite were not measured because of their small diameter and bituminous contamination.

\section{Fluid inclusions}

\subsection{Fluid inclusion petrography and microthermometry}

Microthermometric studies were made on two-phase (liquid-vapor) aqueous fluid inclusions of six samples of Cd-2 dolomite and one porefilling quartz sample. The overview of the microthermometric data is given in Figs. 8b and 9. UV-light observations revealed the presence of oil-bearing fluid inclusions of pale-blue or violet fluorescence, which is typical for light oils or gas condensates (e.g., Stasiuk and Snowdon, 1997; Munz et al., 2002). These oil-bearing inclusions occur in both Cd2 and quartz crystals but they are quite rare (about $2-3 \%$ of the total measured inclusions) and genetically indeterminable; therefore, they were excluded from the detailed examinations.

\subsubsection{Fluid inclusions in $\mathrm{Cd}-2$ dolomite}

Most of the aqueous fluid inclusions (FIs) in the Cd-2 saddle dolomite show variable shape (irregular to negative crystal shape), range in size from about 2 to $15 \mu \mathrm{m}$, and have consistently low vapor/liquid ratios. Each investigated FI homogenized into the liquid phase.

Primary FIs trapped along well-defined growth zones and in the cloudy, inclusion-rich cores of Cd-2 crystals. Homogenization temperatures of these primary inclusions are between 138 and $235^{\circ} \mathrm{C}$ $(\mathrm{n}=146)$, and final melting temperatures are between -2.5 and $-5.7^{\circ} \mathrm{C}(\mathrm{n}=40)$, indicating a salinity range between 4.1 and 8.7 mass $\% \mathrm{NaCl}$ equivalent. Spatial differences in $\mathrm{T}_{\mathrm{h}}$ or $\mathrm{T}_{\mathrm{m}}$ (ice) within the same sample were not observed; however, samples derived from the deeper part of the borehole have significantly higher (in average $30-40{ }^{\circ} \mathrm{C}$ ) $\mathrm{T}_{\mathrm{h}}$ values. For the better visualization of depth-related relationships, data of the aforementioned fluid inclusions are presented on boxplots (Fig. 8b).

Secondary FI assemblages occur along fractures and trails crosscutting the growth zones of the studied Cd-2 dolomite crystals. These FIs have homogenization temperatures ranging from 101 to $217^{\circ} \mathrm{C}$ ( $\mathrm{n}=25)$ and $\mathrm{T}_{\mathrm{m}}$ (ice) from -0.3 to $-23.3(\mathrm{n}=16$ ) (Fig. 9), indicating salinity values between 0.5 and 24.4 mass $\% \mathrm{NaCl}$ equivalent. The low ice melting temperatures indicate the presence of another solute component (e.g., $\mathrm{CaCl}_{2}, \mathrm{MgCl}_{2}$ ) besides $\mathrm{NaCl}$.

High variability in $\mathrm{T}_{\mathrm{h}}$ and $\mathrm{T}_{\mathrm{m}}$ (ice) data may suggest the presence of distinct secondary FIAs or may be the result of post-entrapment modification (e.g., re-opening and fluid mixing or thermal re-equilibration).

\subsubsection{Fluid inclusions in quartz}

The investigated quartz crystals contain two-phase aqueous inclusions, which are situated in groups along crystal-growth planes and can be interpreted as primary in origin. Size of these inclusions ranges between 3 and $70 \mu \mathrm{m}$ and their shapes vary among negative crystal, rounded and amoeboid forms. These inclusions are homogenized to liquid in a relatively narrow temperature range between 117 and $130{ }^{\circ} \mathrm{C}$ $(\mathrm{n}=24)$, while their final ice-melting temperatures range between -13.3 and $-22.6{ }^{\circ} \mathrm{C}(\mathrm{n}=10)$ which indicates a range of salinity values between 17.2 and 24.4 mass $\% \mathrm{NaCl}$ equivalent. The low $\mathrm{T}_{\mathrm{m}}$ (ice) values can be explained by the presence of another solute component (e.g., $\mathrm{CaCl}_{2}, \mathrm{MgCl}_{2}$ ) besides $\mathrm{NaCl}$.

\subsection{Results of Raman microspectroscopy}

Fluorescence of host dolomite and small size of inclusions inhibited Raman analysis of most of the examined FIs. However, at least 37 of 59 

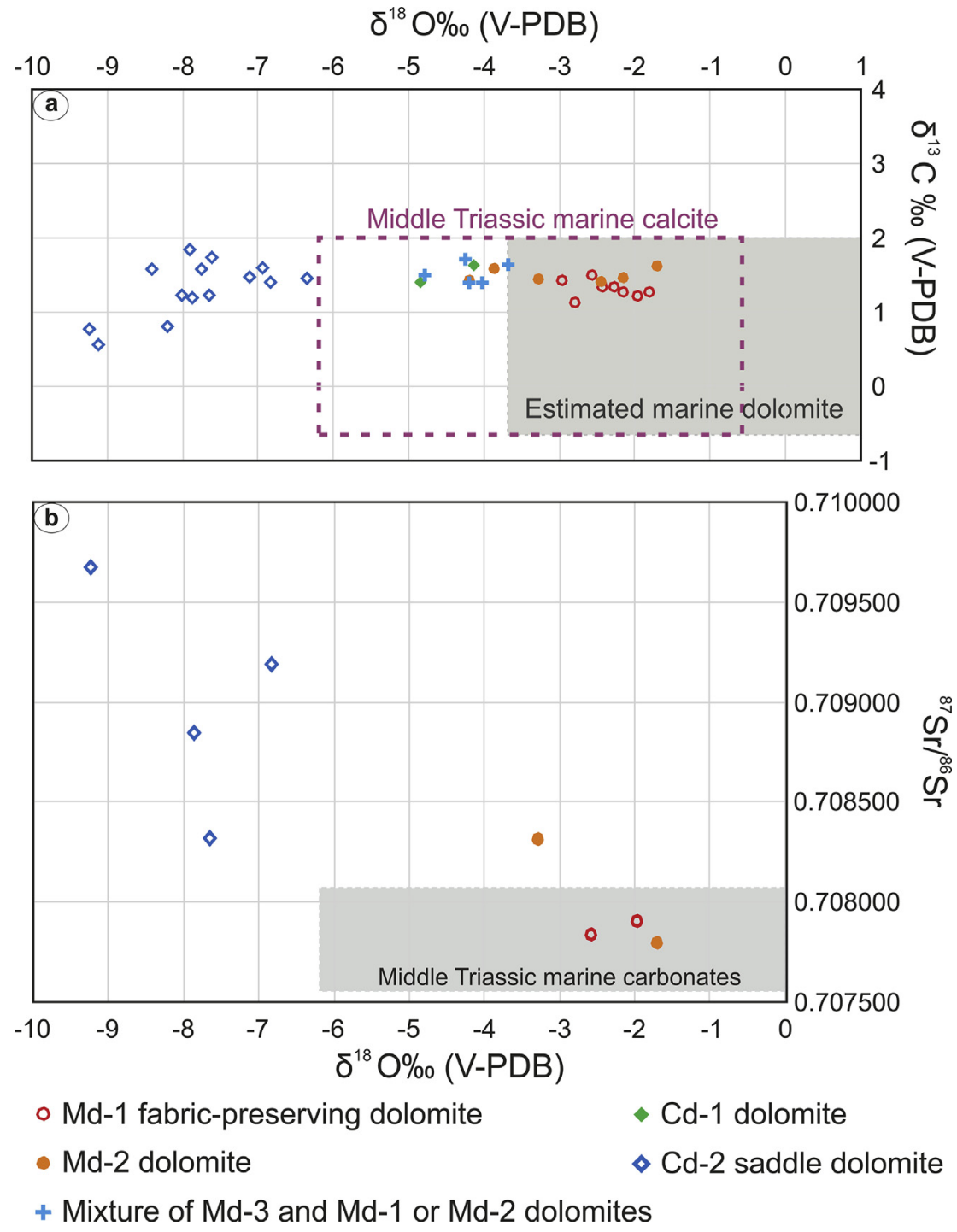

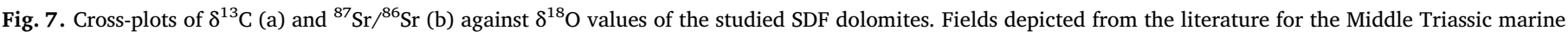
calcite (Korte et al., 2003, 2005) and calculated (cf. Major et al., 1992) for cogenetic marine dolomite.

analyzed fluid inclusions gave interpretable results.

The detected characteristic peaks were the $\mathrm{CH}_{4}\left(2917 \mathrm{~cm}^{-1}\right), \mathrm{N}_{2}$ ( $2331 \mathrm{~cm}^{-1}$ ), $\mathrm{H}_{2} \mathrm{O}$ vapor (board band between 3657 and $3756 \mathrm{~cm}^{-1}$ ) and $\mathrm{H}_{2} \mathrm{O}$ liquid (board bands between 2750 and $3900 \mathrm{~cm}^{-1}$ ) (Frezzotti et al., 2012).

Primary inclusions of Cd-2 dolomite do not contain detectable amounts of Raman-active vapor or liquid species except $\mathrm{H}_{2} \mathrm{O}$. Within the same crystals, analysis of secondary FIs reveals that some of these inclusions contain methane in the vapor phase (Fig. 9a). Each of these methane-bearing inclusions contains only $\mathrm{H}_{2} \mathrm{O}$ in the liquid phase.

The most intensive and characteristic Raman spectra were displayed by FIs hosted in quartz phase (Fig. 10). Most of these fluid inclusions contain $\mathrm{CH}_{4}$ and $\mathrm{N}_{2}$ in the vapor phase, while the coexisting liquid phase contains exclusively $\mathrm{H}_{2} \mathrm{O}$.

\subsection{Hydrogen and oxygen isotopes}

Analytical data on the hydrogen isotopes and the calculated $\delta^{18} \mathrm{O}_{\text {water }}(\mathrm{V}$-SMOW) values of the Cd-2 saddle dolomite forming fluid are plotted in Fig. 11. Water extracted from fluid inclusions of veinfilling Cd-2 saddle dolomite of the M- $1 / 10 / 1$ sample have $\delta D_{\text {water }}(\mathrm{V}$ SMOW) values from -48.3 to $-51.9 \%$ o $(n=3)$. The abundance of the secondary inclusions is considered too low to change significantly the bulk isotopic composition of the extracted water.

The $\delta^{18} \mathrm{O}_{\text {water }}(\mathrm{V}$-SMOW) value of the parent fluid was calculated from the $\mathrm{T}_{\mathrm{h}}$ and $\delta^{18} \mathrm{O}_{\text {Dolomite }}$ values of the same sample, using by the dolomite-water fractionation equation of Land (1983), and vary between +9.2 and $+12.9 \%$ (Figs. 11 and 12 ).

\section{Discussion}

\subsection{Paragenetic sequence}

Based on detailed petrographic and geochemical investigations, the paragenetic sequence is summarized in Fig. 13.

Due to the pervasive dolomitization and subsequent overprinting, only the fabric-retentively dolomitized samples could provide information about the earliest diagenetic processes. These surface and near-surface processes comprise the formation of micritic laminae, fenestral pores, mosaic cement, intraclast re-deposition and encrustation.

The main dolomitization processes resulted in both fabric-retentive and fabric-destructive dolomites, from which the Md-1 and Md-2 phases are predominant in the studied samples. The fabric-retentive Md-1 dolomite contains significant amount of aphanocrystalline to very fine crystalline dolomite and finely crystalline subhedral dolomite mosaics, suggesting that the dolomitization processes probably took 


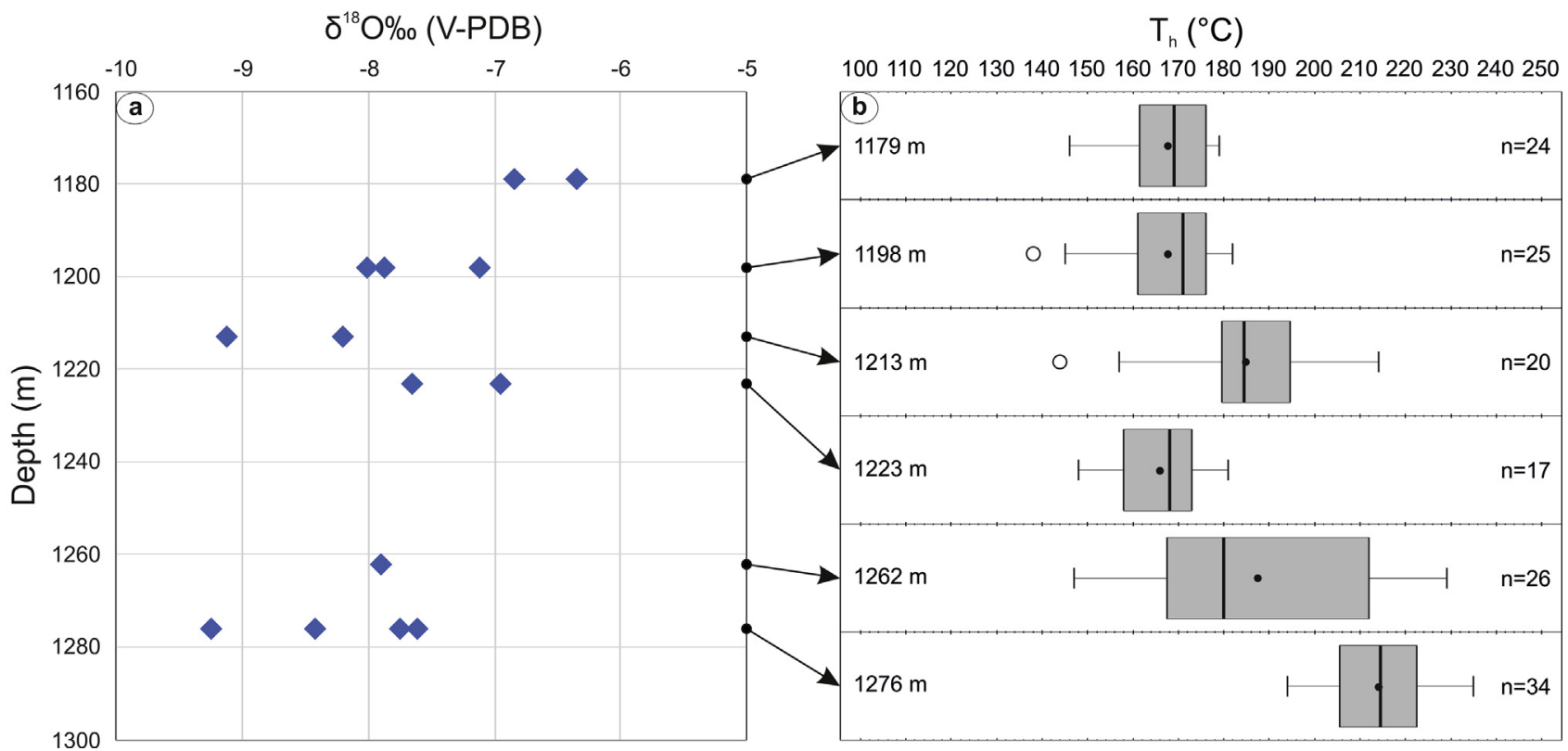

Fig. 8. Depth related $\delta^{18} \mathrm{O}$ and $\mathrm{T}_{\mathrm{h}}$ data measured on $\mathrm{Cd}-2$ dolomite crystals. a) $\delta^{18} \mathrm{O}$ values of $\mathrm{Cd}-2$ saddle dolomites of 6 core samples derived from distinct depths; b) Box-plot diagram showing statistical distribution of $\mathrm{T}_{\mathrm{h}}$ values measured from 146 primary aqueous FIs in 6 samples from distinct depths. In the boxplots, the bottom and the top of the box are the first and third quartiles of the data, while the band inside the box indicates the median value. The ends of the whiskers represent one and a half times the interquartile range (1.5*IQR). Outliers are plotted as individual circles while dots represent mean values of data sets.
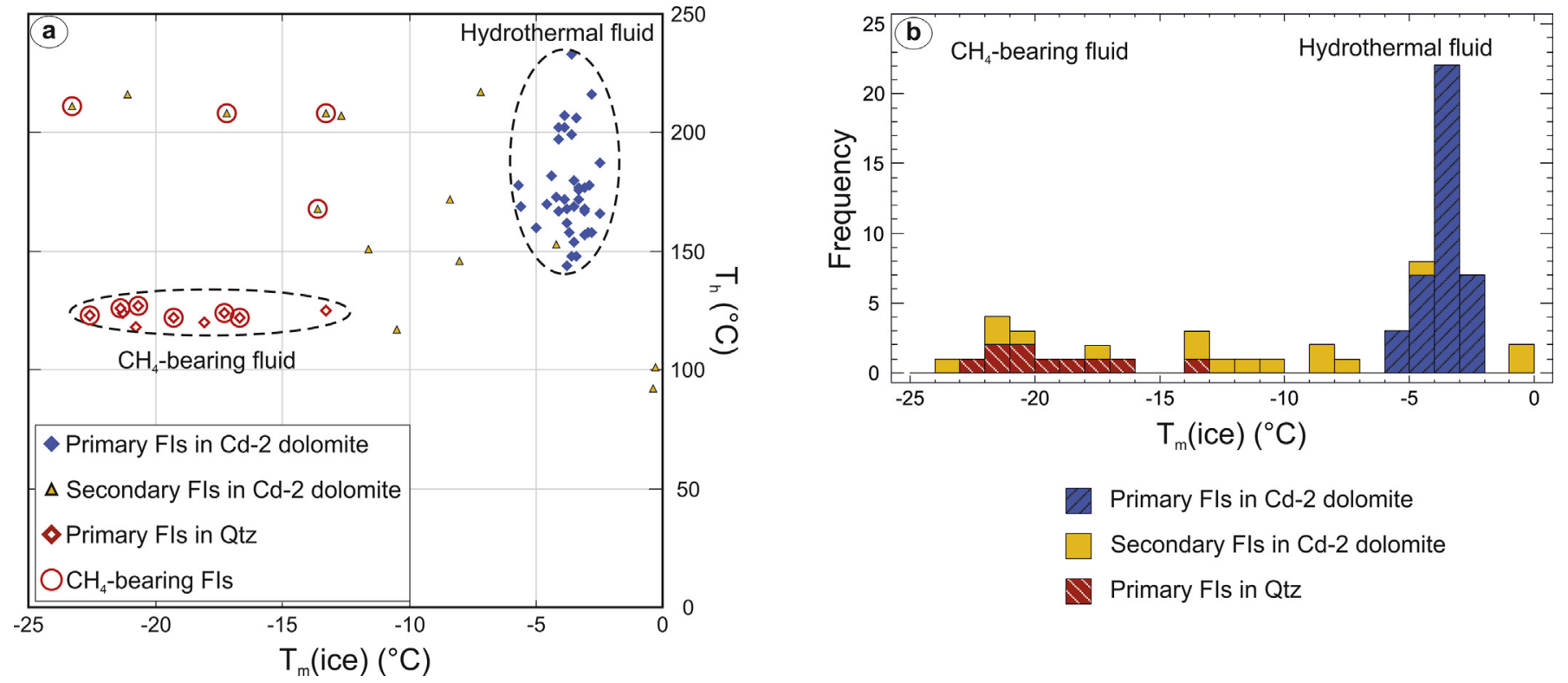

Fig. 9. Graphical presentation of the results of fluid inclusion analyses.

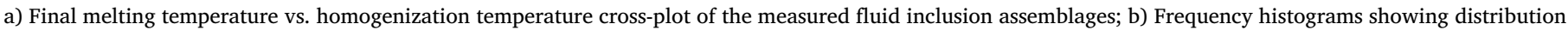
of final ice-melting temperatures of distinct FIAs.

place under near-surface settings (Gregg and Sibley, 1984; Sibley and Gregg, 1987; Machel, 2004).

The distribution of Md-2 dolomite seems generally to overlap with Md-1 dolomite in the sequence, but it shows features indicative to postdating in some cases as well. Both their continuous transition and coexistent appearance in synsedimentary re-deposited intraclasts are documented (Fig. 4d and e). This pattern can be explained by early diagenetic dolomitization which resulted in two different textures. The origin of coexistent fabric-retentive and fabric-destructive dolomites is controversial but can be explained by significantly different porosity or mineralogy of initial carbonate mud, or by different dolomitizing processes within the same carbonate platform (Budd, 1997; Zhao and
Jones, 2012). The very fine to fine crystal size of the Md-2 dolomite and its planar-s texture also support near-surface or shallow burial, lowtemperature conditions (Gregg and Sibley, 1984; Sibley and Gregg, 1987; Machel, 2004).

Coarser crystal size and anhedral crystal mosaics of the Md-3 dolomite, which are commonly associated with the surrounding of fractures and vugs (Fig. 5b and c), point to crystallization at a higher temperature and, probably, at a deeper burial depth (Gregg and Sibley, 1984; Sibley and Gregg, 1987; Machel, 2004). Transitions from Md-1 or Md-2 to Md-3 dolomite and preserved relicts of earlier phases (Fig. $5 \mathrm{f}$ and g) might indicate an aggrading neomorphism process.

Among the cement dolomites, the Cd-1 phase is associated 


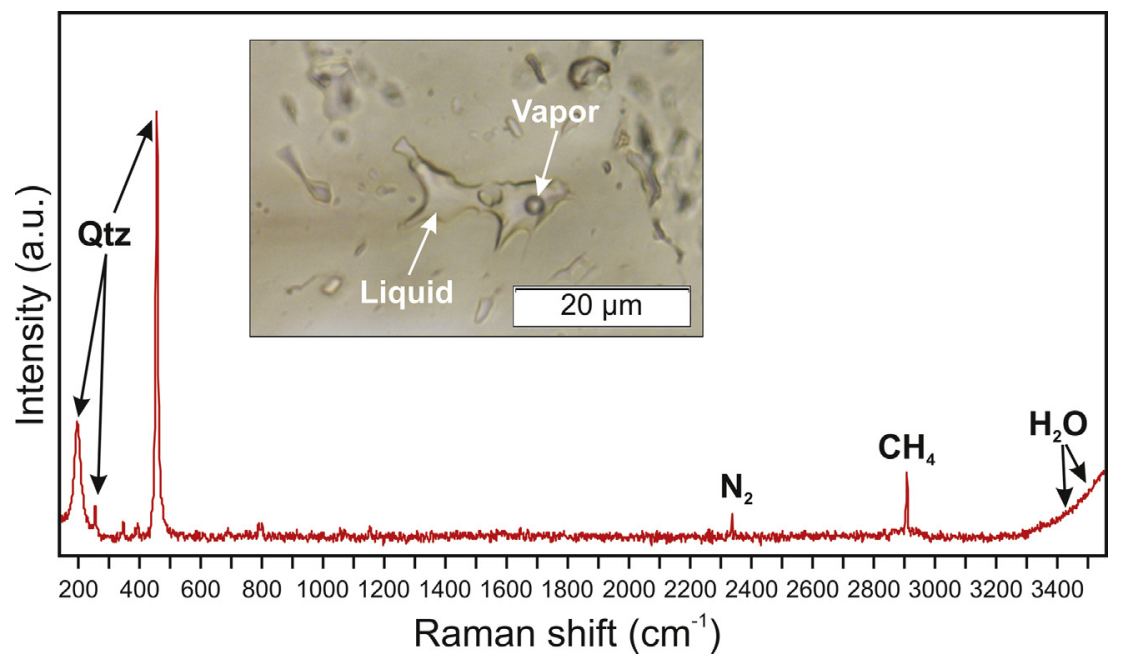

Fig. 10. Representative Raman spectrum of vapor phase within a primary aqueous inclusion of pore-filling quartz. Intensity scale is in arbitrary unit (a.u.).

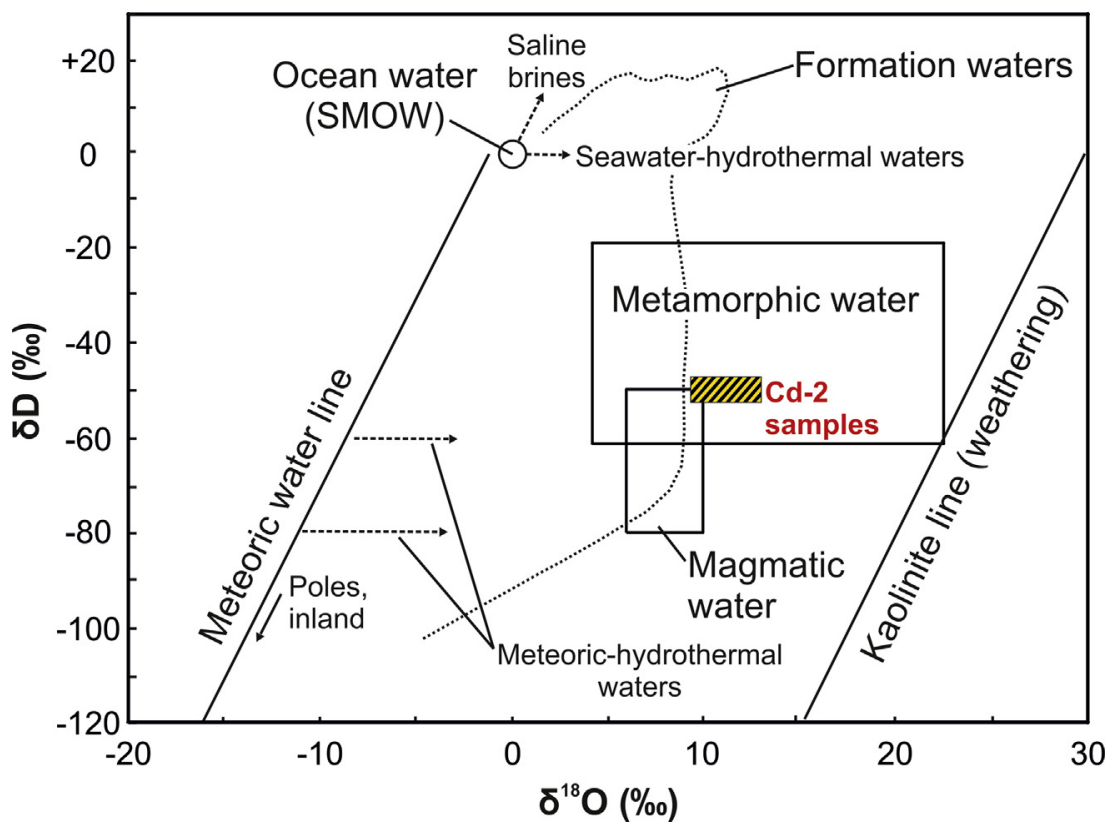

Fig. 11. $\delta \mathrm{D}$ and calculated $\delta^{18} \mathrm{O}$ composition plot (relative to V-SMOW). Field of the Cd-2 saddle dolomite forming fluid is marked by cross-hatched rectangle. Fields of primary waters and transitions are from Sheppard (1986) and Hoefs (2004).

commonly with the intensively brecciated samples representing the lower part of the studied section. This cement type commonly postdates the Md-1 and Md-2 phases but predates the Md-3 and all the other cement phases. These features suggest a relatively early, tectono-genetic origin.

The Cd-2 dolomite postdates the Md-1, Md-2, and Cd-1 phases and shows genetic relationship with the Md-3 dolomite. The presence of the saddle-shaped Cd-2 dolomite cement in vugs and fractures and the associated non-planar Md-3 dolomite in the host rock indicate elevated formation temperature and intermediate to deep-burial setting (Radke and Mathis, 1980; Machel, 2004). Its preferred occurrence in fractures and vugs suggests the relevance of advective fluid flow as a main controlling factor during formation of the Md-3 and Cd-2 dolomites. Presence of the fracture- and pore-filling saddle dolomite in pebbles of the overlaying Middle Miocene abrasional conglomerates is documented (Garaguly et al., 2017), thus the formation of Cd-2 saddle dolomite could precede the Paleogene to Middle Miocene exhumation of the Middle Triassic beds. However, a multiple formation mechanism of the saddle dolomite cements cannot be excluded.
The latest pore-filling phases are calcite, quartz, and Cd-3 dolomite, that postdate all the matrix phases and Cd-2 cement, but their timing relative to each other is uncertain. Among these phases, the calcite is most probably meteoric in origin, as it is documented from similar lithologies and geological settings (e.g., Nader et al., 2004; GomezRivas et al., 2014; Sirat et al., 2016; Mansurbeg et al., 2016; Guo et al., 2016; Dong et al., 2017). The observed cathodoluminescence zonation of calcite crystals (Fig. 6i) also supports this interpretation (Machel, 2000). Juhász et al. (2002) reported similar calcite infills of meteoric origin from the metamorphic basement of the SE Pannonian Basin, thus the studied calcite phase is likely related to the Paleogene to Middle Miocene exhumation of the host formation. The Cd-3 dolomite veins are associated with microstylolites (Fig. 61) suggesting a burial environment which probably took place during the second identified burial stage of the studied rocks, after the Middle Miocene. Hydrocarbon migration is presumably related to the Cd-3 dolomite and quartz precipitation, because bitumen is affiliated to the fractures lined by the Cd3 dolomite. Additionally, methane and $\mathrm{N}_{2}$-bearing primary fluid inclusions are present in quartz cement crystals, which are probably 


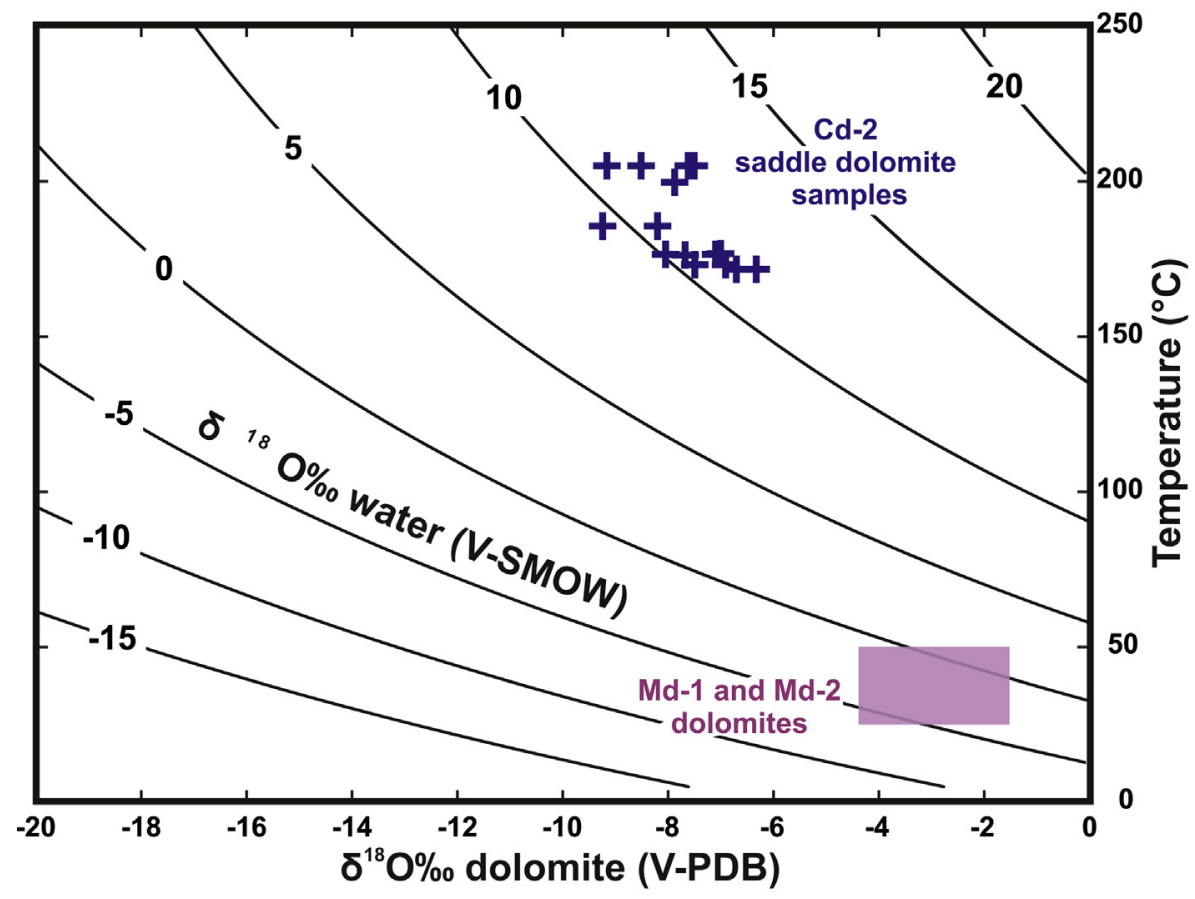

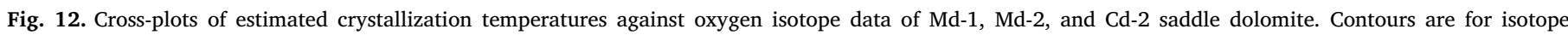
composition of water in isotopic equilibrium with the dolomite, calculated using fractionation equation of Land (1983).

cogenetic with the secondary FIs in saddle dolomite. The aforementioned traces of hydrocarbons are likely to be related to the natural gas reservoir that were explored by the $\mathrm{M}-1$ well.

\subsection{Seawater-controlled early dolomitization processes (dolomitization model for Md-1 and Md-2 phases)}

Pervasive dolomitization of shallow marine calcareous sediments is generally caused by multi-stage processes (Budd, 1997; Warren, 2000; Machel, 2004). Distinction among these dolomitizing mechanisms and explanations of their kinetic background are in the focus of scientific interest since decades. As a result, several theoretical models were proposed (Budd, 1997; Warren, 2000; Machel, 2004) and many fossil records of dolomitic rocks were explained by them. In the case of fossil dolomite occurrences, however, only indirect evidence could contribute to the interpretation. In this section, the main dolomitization processes are presented for Md-1 and Md-2 phases.

From among the widely accepted dolomitization models (e.g., Sun, 1994; Budd, 1997; Warren, 2000; Machel, 2004), the organogenic, the reflux, and the geothermal seawater convection models seem to be plausible processes which could have controlled dolomitization of the main body of the SDF and produce the Md-1 and Md- 2 dolomites.

Several studies have presented the significance of microbial impact on dolomitization of organic-rich peritidal carbonate deposits (Vasconcelos et al., 1995; Wright, 2000; Mastandrea et al., 2006; Bontognali et al., 2010; Preto et al., 2015; Haas et al., 2015; Hips et al., 2015). The presence of similar, microbially mediated primary dolomite or very high-Mg calcite is highly probable in the case of the studied stromatolitic samples. Such primary precipitates could play a significant role during subsequent dolomitization. However, distinction of organogenic dolomite from the mimetic replacements is extremely difficult in a completely dolomitized sediment but might be possible through circumstantial evidence (e.g., Mastandrea et al., 2006; Preto et al., 2015; Pertrash et al., 2017). Thus, this question requires further investigations that fall outside the scope of this study.

During the Late Anisian-Early Ladinian, the investigated area was located around the $30^{\circ} \mathrm{N}$ latitude and was characterized by a semi-arid climate (Szulc, 2000; Feist-Burkhardt et al., 2008). Szurominé Korecz et al. (2018) reported a fossil foraminifer assemblage from the SDF, which they interpreted as a typical stress fauna probably indicating waters of elevated salinity. The presence of desiccation cracks and fenestral pores in the studied peritidal sediments also indicate slightly restricted evaporitic conditions, however, the absence of evaporite minerals and/or their relics suggest that the evaporated sea water did not reach the salinity of the gypsum saturation level. Considering the above findings, mesohaline seawater during the deposition of the studied formations is very likely. Such mesohaline seawater has salinities ranging from $37 \%$ to $140 \%$ (Warren, 2006) and typically plays a key role on reflux dolomitization of the peritidal carbonates (Adams and Rhodes, 1960; Simms, 1984; Sun, 1994; Budd, 1997; Warren, 2000; Qing et al., 2001; Machel, 2004). Consequently, this deposit cannot be regarded as a part of a typical hypersaline sabkha succession, but it likely formed in a semi-arid peritidal environment and a significant part of its dolomitization was resulted by the reflux of the evaporated seawater. Reflux dolomitization is viable for pervasive dolomitization of entire carbonate platforms through a relatively rapid time interval (Whitaker and Smart, 1993; Whitaker et al., 2004; Machel, 2004) but without a better understanding of the geometric configuration and hydrodynamics of the depositional environment of the SDF, a more detailed interpretation cannot be given in a satisfactory manner.

Reflux dolomitization commonly occurs in near-surface settings but it may reach more than $300 \mathrm{~m}$ in depth by density-driven flow of mesohaline seawater (Simms, 1984; Jones et al., 2004). The measured $\delta^{18} \mathrm{O}$ values of Md-1 and Md-2 dolomites do not support completely the reflux dolomitization model as isotopic signatures would be expected to correspond to positive $\delta^{18} \mathrm{O}$ values. Moreover, the observed values might be the result of either influx of fresh water that shifts towards more negative $\delta^{18} \mathrm{O}$ values of precipitates (e.g., Blendinger et al., 2015), or dolomite formation and/or recrystallization at slightly elevated temperatures during subsequent burial (Nielsen et al., 1994).

In summary, the pervasive dolomitization of the studied formation can be considered to reflect the reflux of slightly evaporated seawater (Fig. 14a) under semi-arid conditions. However, minor impact of other dolomitization mechanisms (e.g., microbial dolomitization, geothermal 


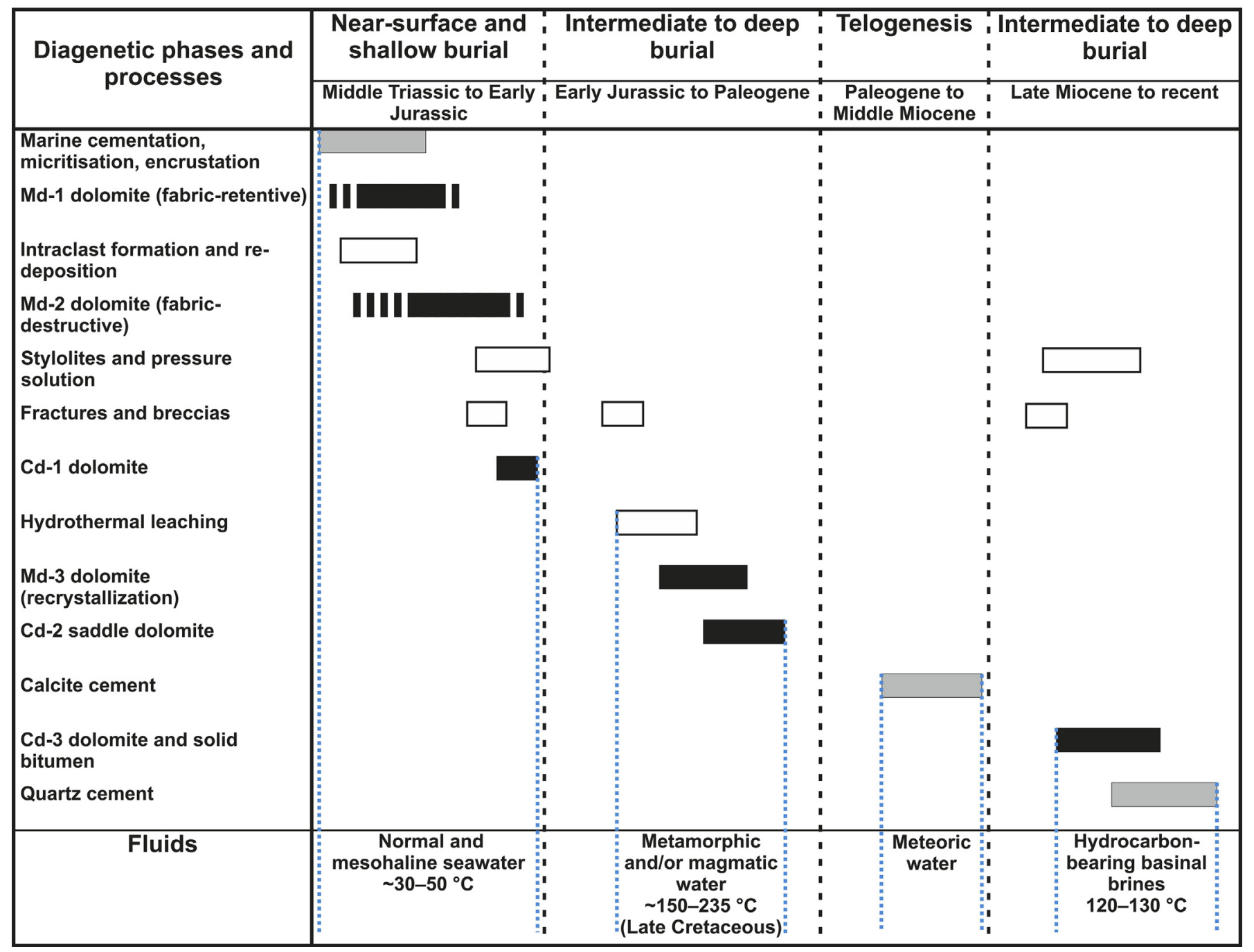

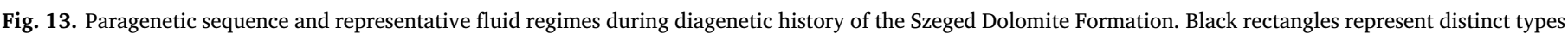

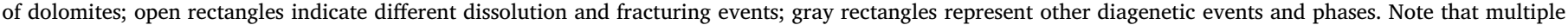
stylolitization is documented by Garaguly et al. (2017).

seawater convection as well as later recrystallization) cannot be excluded. Such combination of mixed dolomitization processes is often referred as the 'seawater dolomitization' model (Machel, 2004).

\subsection{Burial and hydrothermal dolomitization}

\subsubsection{Petrographic evidence of leaching mechanism}

As discussed above (section 4.1.3.), the textural context of the Md-3 dolomite occurrences suggests a genetic relationship with the vug and fracture-forming processes and the Cd-2 dolomite cements. In general, both Md-3 and Cd-2 are found in a close proximity to fractures and oversized dissolution pores (vugs) occur as alteration halos (Figs. 4b and $5 \mathrm{~b}$ and $\mathrm{c}$ ). The Md- 3 dolomite often contains relics of Md- 1 phases (Fig. $5 \mathrm{f}$ and $\mathrm{g}$ ) and shows various forms of textural transitions to earlier dolomite phases (Fig. 5b-h). These observations suggest that the Md-3 dolomite could have formed in two distinct ways: (1) precipitation as tightly packed cement crystals immediately adjacent to fracture walls and oversized vuggy pores; (2) recrystallization of the former Md-1 and Md-2 dolomites, which provided seeds for nucleation of the Md-3 that became nuclei of later dolomite overgrowths.

Textural occurrence of distinct types of dolomites and pores observed in the SDF suggest a similar history to that represented by Lonnee and Machel (2006). Based on this study and our present observations, the studied samples may have undergone the following processes: (1) fractures cut across all previously formed diagenetic phases (Md-1 and Md-2, Cd-1); (2) hydrothermal fluid undersaturated with respect to dolomite were channeled to the rock body along these fractures; (3) significant dissolution took place along the fractures that resulted in enlarged fractures and formation of oversized irregular pores; (4) due to the dissolution of the wall rock, the hydrothermal fluid became saturated with respect to dolomite, consequently the dissolution ceased and replacive nonplanar dolomite (Md-3) formed immediately adjacent to the fracture walls and pores; (5) during the latest stage of hydrothermal flow, the pores and fractures were partially cemented by well-developed Cd-2 saddle dolomite that resulted in the decrease of porosity. The lack of textural or geochemical evidence for recrystallization of earlier matrix dolomites (Md-1 and Md-2) at greater distances from the fractures and vugs suggests the fluid-migration pathway-related alteration.

The increased carbonate solubility can be explained by the cooling of upward-moving formation waters (Giles and de Boer, 1989) but it must be noted that waters of metamorphic origin generally also have significant leaching potential (Cartwright and Oliver, 2000; Yardley and Cleverley, 2013).

\subsubsection{Evidence of hydrothermal fluid flow}

Saddle dolomite (Cd-2) is often considered as an indicator of hydrothermal dolomitization (Davies and Smith, 2006). However, without 


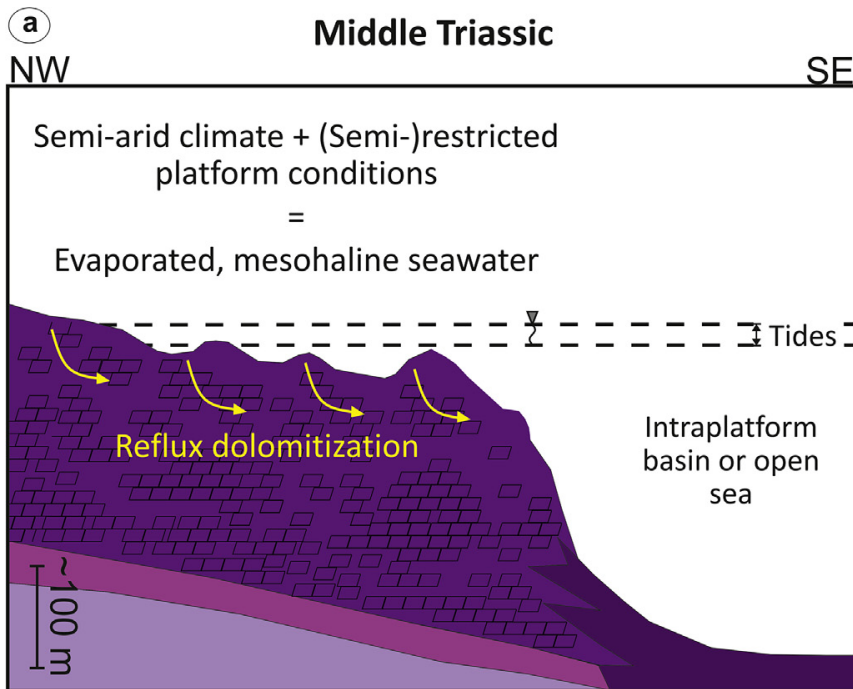

(c)

Middle Miocene
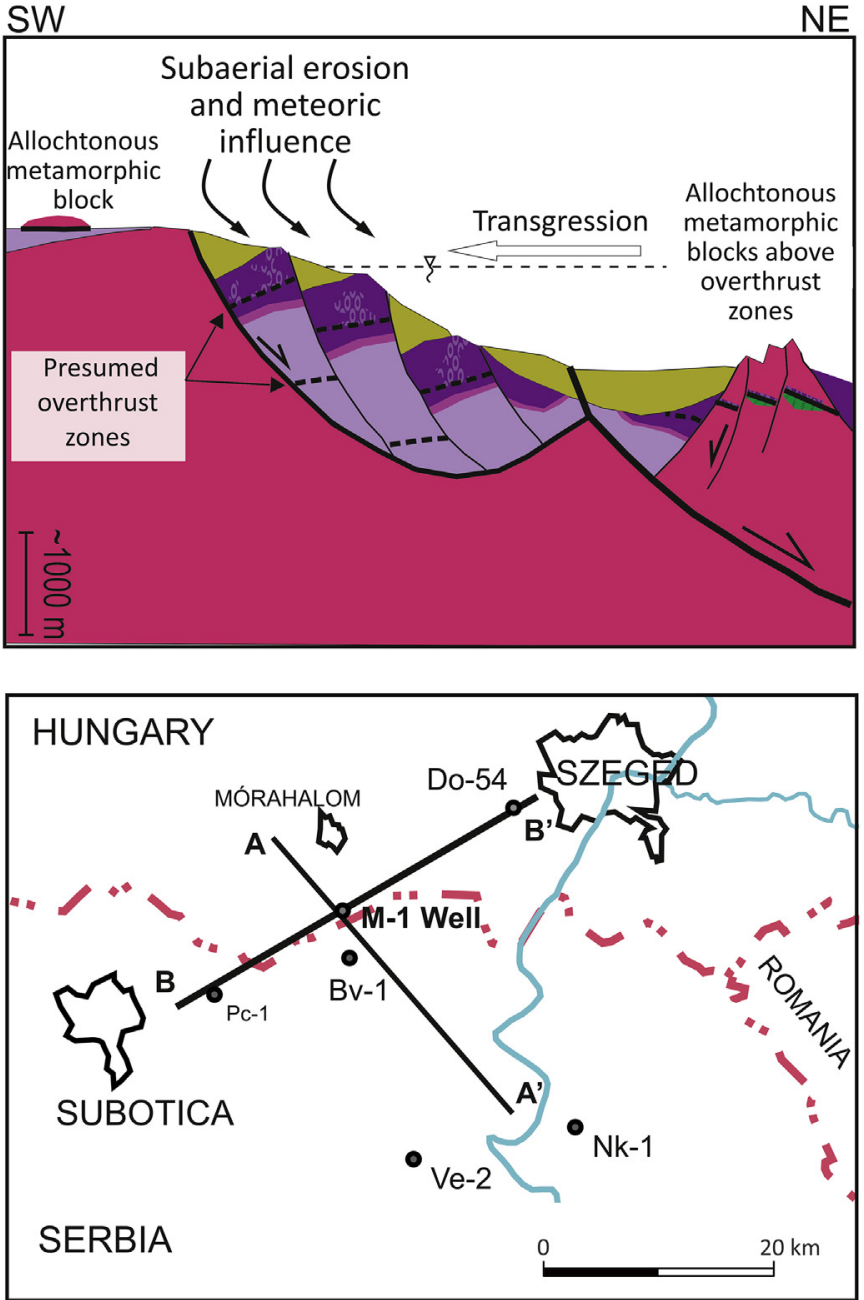

(b) SE NW

Late Cretaceous

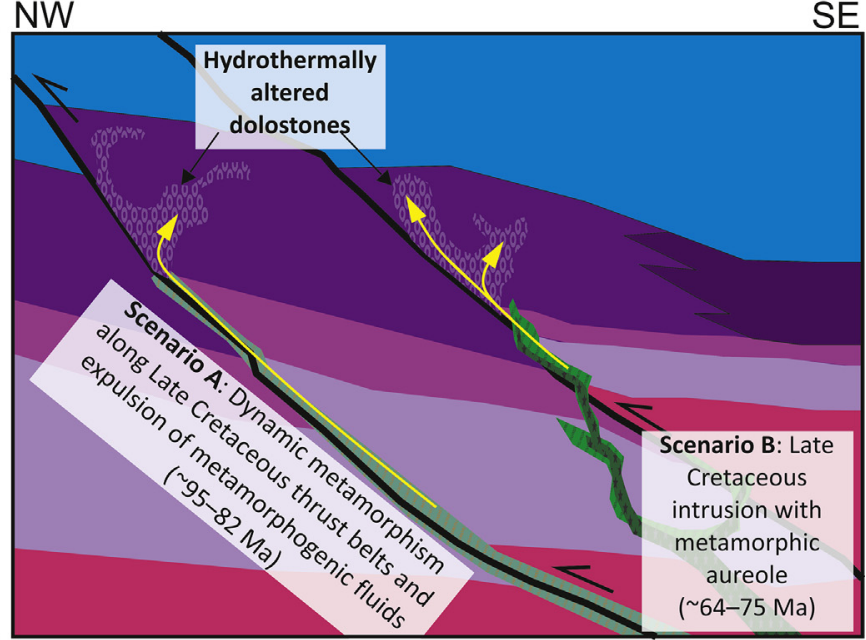

(d) Pliocene-Holocene petroleum system

NE SW

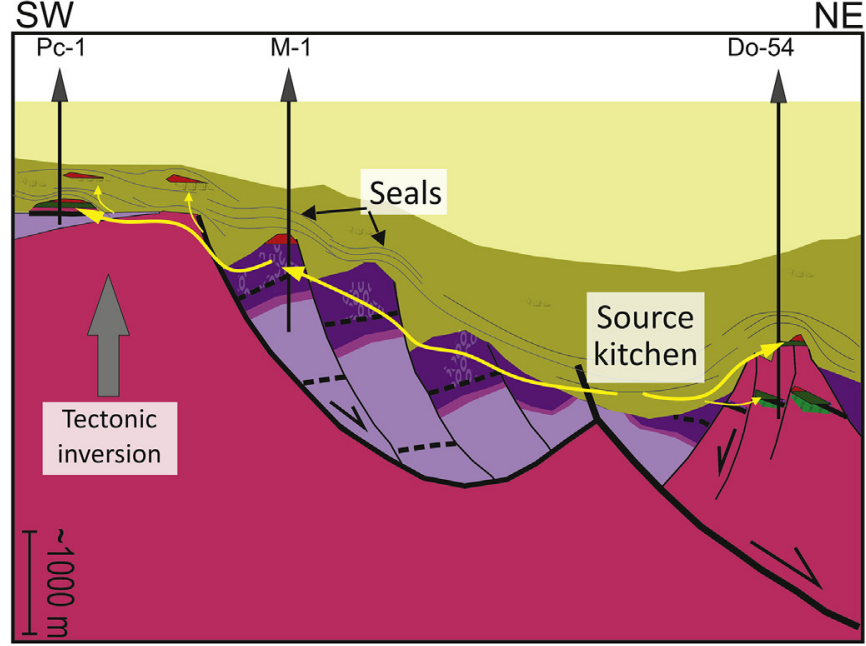

Upper Anisian and Ladinian platform carbonates

Upper Anisian and Ladinian hemipelagic, pelagic carbonates

Lower Anisian ramp shales and dolomarls

Lower Triassic and older siliciclastic sediments

Pre-Mesozoic metamorphic basement

Post-Ladinian Mesozoic formations (hypothetical)

Middle and Upper Miocene sediments

Pliocene and Pleistocene sediments

Oil and gas fields

Fluid flow

Fig. 14. Schematic evolution history and main fluid regimes during diagenesis of the studied SDF reservoir rocks. Wells from the Serbian part of the area refer to Kemenci and Čanović (1997), while the Do-54 well refers to M. Tóth (2008). The western part of the B-B' cross-section is based on the interpreted seismic sections of Tari (1999) and Matenco and Radivojević (2012), that are located close to the studied area.

exact demonstrtion of that the formation temperature was significantly higher than the ambient host rocks temperature, this conclusion is unsubstantiated (Machel and Lonnee, 2002). Proof of a hydrothermal origin for dolomite can be given in several ways, such as combining fluid-inclusion homogenization temperatures with burial-thermal history plots, and by thermal analyses (e.g., vitrinite reflectance, clumped isotopes, fluid inclusions, etc.) to show a higher thermal anomaly with respect to the host rocks within the same stratigraphic succession (e.g., 
Davies and Smith, 2006; Gomez-Rivas et al., 2014; Sirat et al., 2016; Hips et al., 2016; Mansurbeg et al., 2016; Guo et al., 2016; Dong et al., 2017).

Although no spatial differences of the $\mathrm{T}_{\mathrm{h}}$ values were observed in Cd-2 saddle dolomite crystals from the same stratigraphic level, remarkable differences were found among the $\mathrm{T}_{\mathrm{h}}$ values from distinct depths. In addition, it is worth to mention that changes in homogenization temperature were accompanied by simultaneous variations in the $\delta^{18} \mathrm{O}$ values of the Cd-2 saddle dolomite samples (Fig. 8).

Indeed, the six saddle dolomite (Cd-2) samples from different stratigraphic levels show systematic shifts in $\mathrm{T}_{\mathrm{h}}$ values with increasing depth (Fig. 8b). In the upper part of the studied section (1179-1223 m), the samples display $\mathrm{T}_{\mathrm{h}}$ values ranging from 150 to $180^{\circ} \mathrm{C}$ (with one slightly higher volume), while the $\mathrm{T}_{\mathrm{h}}$ values of the sample at the base of the section $(1276 \mathrm{~m})$ vary between 200 and $230^{\circ} \mathrm{C}$. Consequently, the fluid inclusion $\mathrm{T}_{\mathrm{h}}$ data for the six measured $\mathrm{Cd}-2$ dolomite samples fall along a line of slope average $30-50{ }^{\circ} \mathrm{C} / 100 \mathrm{~m}$, which indicates an extreme high heat-flow that could be interpreted as a result of a shortterm hydrothermal imprint.

Additionally, it must be noted that two samples derived from different depths (1262 and $1213 \mathrm{~m}$ ) show transitional signatures between varying temperature end members (Fig. 8). The first one can be interpreted as a transition between two samples, while the second one might be the evidence of a paleotemperature inhomogeneity within a fossil hydrothermal system. The simplest explanation for the relatively largescale changes in temperature with respect to depth might related to corresponding changes in permeability that may refer to variations in fracture density of the host rock. The fact, that the highest temperatures occur in the fractured and brecciated samples also supports this theory.

Alternatively, it is possible to assume that the outlier Th values represent the temperature of hydrothermalism while lower values are in line with the ambient geothermal temperature during the precipitation of saddle dolomite.

Davies and Smith (2006) reported a case study, in which a similar thermal anomaly was interpreted as the result of a short-term, hightemperature transient during hydrothermal fluid flow leading to dolomitization. Such anomaly also reflects the low thermal conductivity of host rocks. Considering the above statements of Davies and Smith (2006), the abrupt temperature gradient over a short distance $\left(30-50{ }^{\circ} \mathrm{C} / 100 \mathrm{~m}\right)$ within the studied section, and the petrographic features demonstrate evidence for a mono-phase, short-term hydrothermal overprint.

\subsubsection{Origin of fluids}

As discussed above, the Md-3 and Cd-2 dolomite phases might indicate hydrothermalism. Therefore, their detailed investigation could provide information about the source of the hydrothermal fluids.

However, no measurable FIs were observed in the Md-3 dolomite crystals but their nonplanar crystal-boundaries together with their affinity to the Cd-2 saddle dolomite support an elevated formation temperature (Gregg and Sibley, 1984). The $\delta^{13} \mathrm{C}$ and $\delta^{18} \mathrm{O}$ data of the samples containing either Md-3/Md-1 or Md-3/Md-2 dolomites fall between the values of the low temperature dolomites (Md-1 and Md-2) and high temperature Cd-2 saddle dolomite (Fig. 7a), reflecting a mixture of these two end members. Thus, the pristine Md-3 dolomites may have similar $\delta^{18} \mathrm{O}$ values as those of the $\mathrm{Cd}-2$ dolomite.

The significantly higher ${ }^{87} \mathrm{Sr} /{ }^{86} \mathrm{Sr}$ ratio of the Cd-2 dolomite than those of the matrix dolomites (Md-1, Md-2) is a common feature (Fig. 7b), that may be explained by the source of fluids or by enhanced water-rock interaction during fluid flow (Banner, 1995). Additionally, the similar $\delta^{13} \mathrm{C}$ values of the studied dolomite types suggest that carbon was inherited from the host dolostones (Hoefs, 2004). The fact that the homogenization temperatures change in line with oxygen isotope data (Figs. 8 and 12) suggests an equilibrium isotope fractionation during precipitation of the Cd-2 dolomite cement (Land, 1983).

Combining the fluid-inclusion homogenization temperatures with the $\delta^{18} \mathrm{O}$ values from the Cd-2 dolomites and applying the dolomite$\mathrm{H}_{2} \mathrm{O}$ fractionation equation of Land (1983), it can be stated that all Cd-2 saddle dolomite samples were formed from a fluid with a composition ranging from +9.2 to $+12.9 \% \delta^{18} \mathrm{O}_{\text {water }}(\mathrm{V}-\mathrm{SMOW}$ ) (Fig. 12). These values fall on the border of magmatic and metamorphic waters composition (Sheppard, 1986; Hoefs, 2004) but due to the fact that $\mathrm{T}_{\mathrm{h}}$ values represent the minimum trapping temperatures (Goldstein and Reynolds, 1994), the calculated $\delta^{18} \mathrm{O}_{\text {water }}(\mathrm{V}-\mathrm{SMOW})$ values probably underestimate the original fluid composition. Hence, pressure correction of the homogenization temperatures would increase the calculated $\delta^{18} \mathrm{O}_{\text {water }}(\mathrm{V}-\mathrm{SMOW})$ values and shift them into the field of metamorphic waters.

Additionally, both the calculated $\delta^{18} \mathrm{O}_{\text {water }}(\mathrm{V}-\mathrm{SMOW})$ and the measured $\delta \mathrm{D}_{\text {water }}(\mathrm{V}-\mathrm{SMOW})$ values of the FIs from the Cd-2 dolomite indicate a metamorphic origin of the fluid with some magmatic affinity (Fig. 11). This suggests that either one or both of them have contributed to the hydrothermal alteration of the SDF.

Such an isotopic enrichment must be accompanied by corresponding increase in salinity during the evolution of formation waters (Sheppard, 1986; Hoefs, 2004). Thus, the moderate salinity (4.17-8.67 mass $\% \mathrm{NaCl}$ equivalent) measured from the primary FIs of Cd-2 dolomites paired with high $\delta^{18} \mathrm{O}_{\text {water }}$ values also support the proposed origin of fluids. According to several authors (Mullis et al., 1994; Cartwright and Oliver, 2000; Pohl, 2011; Yardley and Cleverley, 2013) the devolatilization of rocks undergoing metamorphism could lead to similar, low-salinity and $\delta^{18} \mathrm{O}$-enriched metamorphogenic fluids.

\subsubsection{Timing of hydrothermal alteration}

Timing of the aforementioned hydrothermal dolomitization and formation of the connecting porosity is more difficult than in the case of early diagenetic matrix dolomites, but it might be possible through the combination of indirect geochemical evidence and the regional geology of the studied area. Fortunately, events that can serve as a source of metamorphic (scenario A) and/or magmatic fluids (scenario B) in the study area, are restricted into a relatively narrow time interval during the Late Cretaceous. These are the Turonian-Coniacian (Pre-Gosau) nappe-stacking event and the subsequent calc-alkaline intrusive magmatism during the Campanian-Maastrichtian (Haas and Péró, 2004; Szederkényi et al., 2013).

7.3.4.1. Scenario A: prograde metamorphic fluids. The Late Cretaceous orogenic phase resulted in widespread occurrence of subhorizontal north-northwest-vergent thrusts throughout the studied area (e.g., Tari et al., 1999; Matenco and Radivojević, 2012; Szederkényi et al., 2013). Locally, thrusting induced a retrograde metamorphic overprint of the Variscan crystalline basement rocks and caused a prograde metamorphism of the post-Variscan sequences along overthrust zones (Árkai et al., 2000; Árkai, 2001).

Furthermore, several studies highlighted the significance of the Late Cretaceous overthrust zones as fluid migration pathways (e.g., M. Tóth, 2008; Papp et al., 2017). Additionally, corresponding to the increased secondary porosity of the fractured basement zones, their hydrocarbon storage capacity is also remarkable in the SE Pannonian Basin (Juhász et al., 2002; Schubert et al., 2007; M. Tóth, 2008; Molnár et al., 2015; Papp et al., 2017).

About 15-20 km northeast from the M - 1 well, a few-meter-thick marble body was found along a shear zone within the metamorphic basement (Do-54 well on Fig. 14). This marble might be formed by the Late Cretaceous prograde metamorphism of the Mesozoic formations (M. Tóth et al., 2017; Papp et al., 2017). Furthermore, it must be noted that the marble body shows signs of post-metamorphic hydrothermal alterations such as sulphide-mineralization and pore-filling saddle dolomite (M. Tóth et al., 2017; Papp et al., 2017).

There are several models to explain how metamorphic fluids form and are expelled into regions of lower pressure. One of these is the "prograde metamorphogenic" model, in which the shear zones focuses 
upflow of metamorphic fluids because of higher permeability (Oliver, 1986; Pohl, 2011 and references therein). This model seems applicable to the studied formations.

Hydrothermal dolomitization induced by compressional tectonism is also a well-documented phenomenon (e.g., Ronchi et al., 2012; Sirat et al., 2016; Mansurbeg et al., 2016; Dong et al., 2017); however, in contrast with our interpretation, in the most cases the hydrothermal fluids are identified as basinal brines or mixed magmatic and formational waters.

Considering the above findings, the fluids highly enriched in $\delta^{18} \mathrm{O}$ may have been derived from metamorphic devolatilization of a postVariscan-Mesozoic formation and the thrust zones within the SDF dolomite body could be the possible pathways for upflowing fluids (Fig. 14b).

7.3.4.2. Scenario B: contact metamorphic fluids. The presence of the Upper Cretaceous banatite intrusions within the SE Pannonian Basin is widely accepted and referred by numerous authors (e.g., Horváth and Árkai, 2002; Lelkes-Felvári et al., 2003; Haas and Péró, 2004; M. Tóth, 2008; Szederkényi et al., 2013); however, their detailed analysis and geodynamic interpretation within the Alpine-Carpathian-Dinaric tectonic system have not been done yet. Nevertheless, the banatitic magmatism is well-documented in the Apuseni Mountains (e.g., Berza et al., 1998; Merten et al., 2011; Ciobanu et al., 2002; Neubauer, 2002 and references therein), in the eastern part of the Tisza mega-unit. Therefore, the Apuseni Mountains have a more or less analogue geological evolution than that of the studied area (Haas and Péró, 2004).

The banatitic magmatism in the Apuseni Mountains and the Banat region was frequently accompanied by thermal and metasomatic transformation of the surrounding rocks. The most typical products of these transformations in the contact aureoles of the banatites are skarns and hydrothermal alterations (Ilinca et al., 2011; Ilinca, 2012 and references therein). Several types of skarns have been distinguished (Vlad, 1997) and some of them may develop along magmatic-sedimentary contacts but they often form distal bodies along fractures or thrust planes or highly brecciated metasomatic columns. Cases of large scale $\mathrm{Ca} \Leftrightarrow \mathrm{Mg}$ transfer reactions, resulting in dolomitization of limestones or in dedolomitization, have also been observed (Vlad, 1997; Ilinca et al., 2011; Ilinca, 2012 and references therein).

Mantle-derived magma has typically low ${ }^{87} \mathrm{Sr} /{ }^{86} \mathrm{Sr}$ ratios and this feature makes fluids of such origin distinguishable (e.g., Dong et al., 2013; Jacquemyn et al., 2014). However, corresponding to the upper crustal contamination (Berza et al., 1998), banatites of the Apuseni Mountains yield elevated ${ }^{87} \mathrm{Sr} /{ }^{86} \mathrm{Sr}$ ratios (up to 0.709). This elevated radiogenic strontium content reconciles more or less with the enriched radiogenic Sr content of the studied Cd-2 saddle dolomite.

According to the previous papers, several hydrothermal dolomite occurrences were documented as byproduct of intrusive magmatism (e.g., Lavoie et al., 2010; Dong et al., 2013; Jacquemyn et al., 2014; Dong et al., 2017). Some of them occur in the immediate vicinity of the contact metamorphic marble bodies (e.g., Dong et al., 2013; Jacquemyn et al., 2014), but the contribution of metamorphogenic waters is generally subordinate and/or underestimated.

In conclusion, magmatic and/or contact-metamorphic origin of the hydrothermal fluids related to the crystallization of the studied SDF saddle dolomites is also possible (Fig. 14b).

\subsection{Reservoir formation and hydrocarbon accumulation}

Dolomite hydrocarbon reservoirs generally contain multiple generations of dolomite and porosity (Machel, 2004). Understanding their genesis and timing relative to hydrocarbon maturation and migration could aid in exploration and development.

As discussed above, the studied reservoir rocks contain significant amount of secondary porosity that were formed by the leaching effect of the hydrothermal fluids during the Late Cretaceous. After the Cretaceous, long-standing exhumation processes affected the study area that resulted in the erosion of overlying sequences and the deposition of Middle Miocene abrasional sediments. Meteoric calcite cements could have been connected to this subaerial exposure stage (Fig. 14c). During this time, the previously formed vuggy and fractured porosity were partly occluded but a remarkable part was preserved, and currently serves as reservoir space.

Considering the basement maps (Fig. 2) and interpreted seismic transects compiled from the surrounding of the studied area (Tari et al., 1999; Matenco and Radivojević, 2012), it can be stated that the M - 1 exploration well is probably located in the northeastern flank of a large basement high and was drilled above the top of a roll-over anticline and/or rotated basement blocks, that were formed during and/or after the Middle Miocene syn-rift phase. After the basin subsidence, during the Late Miocene an inversion phase is also characteristic, while the basement was covered by Middle Miocene to Quaternary sediments (Radivojević et al., 2010; Pigott and Radivojević, 2010; Matenco and Radivojević, 2012). All these processes could have led to the formation of structural traps on the top of the Middle Triassic sequences covered by Middle to Upper Miocene seals.

According to numerous authors (Dank, 1988; Teleki et al., 1994; Badics and Vetö, 2012 and references therein), the recently produced hydrocarbons of the basement highs of the SE part of the Pannonian Basin most likely were generated in the adjacent overpressured subbasins, and the sources of the hydrocarbons are believed to be the Middle to Upper Miocene shales. Such a deep sub-basin with thick Neogene sequences is located northeast of the studied $M-1$ well. Thus, the reservoir exposed by the $\mathrm{M}-1$ well likely was charged from these Neogene sequences through the fractured rocks of the pre-Neogene basement (Fig. 14d).

The hydrocarbon charge of the reservoir probably occurred from the Late Miocene or Pliocene to present-day and is indicated by: (1) methane and $\mathrm{N}_{2}$-bearing primary fluid inclusions in the pore filling quartz phase; (2) methane-bearing secondary fluid inclusions in the saddle dolomite, (3) late-stage bitumeniferous dolomite veins (Cd-3).

\section{Conclusions}

Based on detailed petrographic and geochemical investigations as well as carbon, oxygen, hydrogen and strontium isotope analyses, the following conclusions can be drawn about the studied reservoir rocks:

1 The studied Middle Triassic Szeged Dolomite Formation was deposited in a carbonate platform under semi-arid conditions. The main dolomitizing processes were controlled by the reflux and density-driven circulation of mesohaline seawater in the ancient platform. These processes took place from the near surface realm and by the time the succession passed through the shallow burial realm, it was completely dolomitized.

2 The nonplanar matrix dolomite (Md-3) and the saddle dolomites (Cd-2) are not cogenetic with the earlier types of the matrix dolomites. Instead, they formed through the high temperature alteration of matrix dolomite by way of invasion of exotic fluids.

3 The results of fluid inclusion analysis of saddle dolomite suggest an extremely high, $30-50{ }^{\circ} \mathrm{C} / 100 \mathrm{~m}$ paleogeothermic gradient that could be explained by the heating effect of a mono-phase, relatively short-term hydrothermal fluid flow. The temperature differences may relate to the inhomogeneous permeability distribution within a fracture-related hydrothermal system.

4 Based on the calculated $\delta^{18} \mathrm{O}_{\text {water }}$ and fluid inclusion $\delta \mathrm{D}_{\text {water values, }}$ the hydrothermal fluids are metamorphogenic and/or magmatic in origin and they probably were channeled along the Upper Cretaceous subhorizontal overthrust zones.

5 The studied reservoir rocks contain significant amount of secondary porosity that were formed by the leaching effect of the hydrothermal 
fluids during the Late Cretaceous. These pores were partly occluded by meteoric calcite during the Paleogene-Middle Miocene subaerial exposure but a remarkable part was preserved.

6 Methane-bearing primary fluid inclusions in the pore filling quartz phase, secondary fluid inclusions in the saddle dolomite, and the late-stage bituminiferous dolomite veins ( $\mathrm{Cd}-3)$ indicate that the hydrocarbon charging of the reservoir occurred from the Late Miocene or Pliocene to present-day.

\section{Acknowledgments}

This research was supported by the National Research, Development and Innovation Fund of Hungary (project no. K 108375). The authors would like to thank MOL Plc for providing the core material that were essential for this research. We would like to thank Dr. Fadi H. Nader and the anonymous referee for their suggestions and comments that improve our manuscript, as well as Associated Editor Dr. Ihsan Al-Aasm for the editorial work.

\section{References}

Adams, J.E., Rhodes, M.L., 1960. Dolomitization by seepage refluxion. AAPG (Am. Assoc. Pet. Geol.) Bull. 44, 1912-1920.

Árkai, P., 2001. Alpine regional metamorphism in the main tectonic units of Hungary: a review. Acta Geol. Hung. 44, 329-344.

Árkai, P., Bércziné Makk, A., Balogh, K., 2000. Alpine low-t prograde metamorphism in the post-variscan basement of the Great Plain, Tisza unit (Pannonian Basin, Hungary). Acta Geol. Hung. 43, 43-64.

Badics, B., Vető, I., 2012. Source rocks and petroleum systems in the Hungarian part of the Pannonian Basin: the potential for shale gas and shale oil plays. Mar. Petrol. Geol. 31, 53-69.

Banner, J.L., 1995. Application of the trace element and isotope geochemistry of strontium to studies of carbonate diagenesis. Sedimentology 42, 805-824.

Bércziné Makk, A., 1986. Mesozoic formation types of the Great Hungarian plain. Acta Geol. Hung. 29, 261-282.

Berza, T., Constantinescu, E., Vlad, S.N., 1998. Upper Cretaceous magmatic series and associated mineralisation in the Carpathian-Balkan orogen. Resour. Geol. 48, 291-306.

Bleahu, M., Mantea, G., Bordea, S., Panin, S., Stefănescu, M., Sikić, K., Haas, J., Kovács, S., Péró, Cs, Bérczi-Makk, A., Konrád, Gy, Nagy, E., Rálisch-Felgenhauer, E., Török, Á., 1994. Triassic facies types, evolution and paleogeographic relations of the Tisza Megaunit. Acta Geol. Hung. 37, 187-234.

Blendinger, W., Lohmeier, S., Bertini, A., Meißner, E., Sattler, C.D., 2015. A new model for the formation of dolomite in the Triassic dolomites, Northern Italy. J. Petrol. Geol. 38, 5-36.

Bodnar, R.J., 1993. Revised equation and table for determining the freezing point depression of $\mathrm{H}_{2} \mathrm{O}-\mathrm{NaCl}$ solutions. Geochem. Cosmochim. Acta 57, 683-684.

Bontognali, T.R.R., Vasconcelos, C., Warthmann, R.J., Bernasconi, S.M., Dupraz, C., Strohmenger, C.J., McKenzie, J.A., 2010. Dolomite formation within microbial mats in the coastal sabkha of Abu Dhabi (United Arab Emirates). Sedimentology 57, 824-844.

Budd, D.A., 1997. Cenozoic dolomites of carbonate islands: their attributes and origin. Earth Sci. Rev. 42, 1-47.

Cartwright, I., Oliver, N., 2000. Metamorphic fluids and their relationship to the formation of metamorphosed and metamorphogenic ore deposits. Rev. Econ. Geol. 11, $81-95$.

Ciobanu, C.L., Cook, N.J., Stein, H., 2002. Regional setting and geochronology of the Late Cretaceous Banatitic Magmatic and Metallogenetic Belt. Miner. Deposita 37, $541-567$.

Csontos, L., Vörös, A., 2004. Mesozoic plate tectonic reconstruction of the Carpathian region. Palaeogeogr. Palaeoclimatol. Palaeoecol. 210, 1-56.

Csontos, L., Nagymarosy, A., Horváth, F., Kovács, M., 1992. Cenozoic evolution of the Intra-Carpathian area: a model. Tectonophysics 208, 221-241.

Czuppon, Gy, Ramsay, R.R., Özgenc, I., Demény, A., Gwalani, L.G., Rogers, K., Eves, A., Papp, L., Palcsu, L., Berkesi, M., Downes, P.J., 2014. Stable (H, O, C) and noble-gas (He and $\mathrm{Ar}$ ) isotopic compositions from calcite and fluorite in the Speewah Dome, Kimberley Region, Western Australia: implications for the conditions of crystallization and evidence for the influence of crustal-mantle fluid mixing. Minerology and Petrology 108, 759-775.

Dank, V., 1988. Petroleum geology of the Pannonian Basin. In: In: Royden, L.H., Horváth, F. (Eds.), The Pannonian Basin, a Study in Basin Evolution. AAPG Memoir, vol. 45. pp. 319-332.

Davies, G.R., Smith, L.B., 2006. Structurally controlled hydrothermal dolomite reservoirs facies: an overview. AAPG (Am. Assoc. Pet. Geol.) Bull. 90, 1641-1690.

Demény, A., Czuppon, G., Kern, Z., Leél-Őssy, S., Németh, A., Szabó, M., Tóth, M., Wu, C.C., Shen, C.-C., Molnár, M., Németh, T., Németh, P., Óvári, M., 2016. Recrystallization-induced oxygen isotope changes in inclusion-hosted water of speleothems - paleoclimatological implications. Quat. Int. 415, 25-32.

Dickson, J.A.D., 1966. Carbonate identification and genesis as revealed by staining. J.
Sediment. Res. 36, 491-505.

Dong, S., Chen, D., Qing, H., Zhou, X., Wang, D., Guo, Z., Jiang, M., Qian, Y., 2013. Hydrothermal alteration of dolostones in the Lower Ordovician, Tarim Basin, NW China: multiple constraints from petrology, isotope geochemistry and fluid inclusion microthermometry. Mar. Petrol. Geol. 46, 270-286.

Dong, S., Chen, D., Zhou, X., Qian, Y., Tian, M., Qing, H., 2017. Tectonically driven dolomitization of Cambrian to Lower Ordovician carbonates of the Quruqtagh area, north-eastern flank of Tarim Basin, north-west China. Sedimentology 64, 1079-1106.

Dövényi, P., Horváth, F., 1988. A review of temperature, thermal conductivity, and heat flow data from the Pannonian basin. In: In: Royden, L.H., Horváth, F. (Eds.), The Pannonian Basin: a Study in basin Evolution, vol. 45. AAPG Memoir, pp. 195-233.

Feist-Burkhardt, S., Götz, A.E., Szulc, J., Borkhataria, R., Geluk, M., Haas, J., Hornung, J., Jordan, P., Kempf, O., Michalik, J., Nawrocki, J., Reinhardt, L., Ricken, W., Röhling, H.-G., Rüffer, T., Török, Á., Zühlke, R., 2008. Triassic. In: In: McCann, T. (Ed.), The Geology of Central Europe, vol. 2. pp. 749-821 Mesozoic and Cenozoic, Geological Society of London.

Frezzotti, M.L., Tecce, F., Casagli, A., 2012. Raman spectroscopy for fluid inclusion analysis. J. Geochem. Explor. 112, 1-20.

Garaguly, I., Raucsik, B., Varga, A., Schubert, F., 2017. Diagenetic and brittle deformation history of Middle Triassic dolomites in the Szeged Basin, southeast Hungary. Földtani Közlony 147, 39-60 (in Hungarian with English abstract).

Giles, M.R., de Boer, R.B., 1989. Secondary porosity: creation of enhanced porosities in the subsurface from the dissolution of carbonate cements as a result of cooling formation waters. Mar. Petrol. Geol. 6, 261-269.

Goldstein, R.H., Reynolds, T.J., 1994. Systematics of Fluid Inclusions in Diagenetic Minerals. SEPM Short Course 31. Society of Sedimentary Geology 203 p.

Gomez-Rivas, E., Corbella, M., Martín-Martín, J.D., Stafford, S.L., Teixell, A., Bons, P.D., Cardellach, E., 2014. Reactivity of dolomitizing fluids and Mg source evaluation of fault-controlled dolomitization at the Benicàssim outcrop analogue (Maestrat Basin, E Spain). Mar. Petrol. Geol. 55, 26-42.

Gregg, J.M., Sibley, D.F., 1984. Epigenetic dolomitization and the origin of xenotopic dolomite texture. J. Sediment. Res. 54, 908-931.

Guo, C., Chen, D., Qing, H., Dong, S., Li, G., Wang, D., Qian, Y., Liu, C., 2016. Multiple dolomitization and later hydrothermal alteration on the Upper Cambrian-Lower Ordovician carbonates in the northern Tarim Basin, China. Mar. Petrol. Geol. 72, 295-316.

Haas, J., Péró, C.S., 2004. Mesozoic evolution of the Tisza mega-unit. Int. J. Earth Sci. 93 , 297-313.

Haas, J., Hámor, G., Korpás, L., 1999. Geological setting and tectonic evolution of Hungary. Geol. Hung. Ser. Geol. 24, 179-196.

Haas, J., Budai, T., Csontos, L., Fodor, L., Konrád, Gy., 2010. Pre-cenozoic Geological Map of Hungary 1:500 000. Hungarian Geological Institute.

Haas, J., Lukoczki, G., Budai, T., Demény, A., 2015. Genesis of Late Triassic peritidal dolomites in the Transdanubian Range, Hungary. Facies 61, 8.

Haas, J., Hips, K., Budai, T., Győri, O., Lukoczki, G., Kele, S., Demény, A., Poros, Zs, 2017. Processes and controlling factors of polygenetic dolomite formation in the Transdanubian Range, Hungary: a synopsis. Int. J. Earth Sci. 106, 991-1021.

Hips, K., Haas, J., Poros, Zs, Kele, S., Budai, T., 2015. Dolomitization of Triassic microbial mat deposits (Hungary): origin of microcrystalline dolomite. Sediment. Geol. 318, $113-129$.

Hips, K., Haas, J., Győri, O., 2016. Hydrothermal dolomitization of basinal deposits controlled by a synsedimentary fault system in Triassic extensional setting. Hungary. International Journal of Earth Sciences 105, 1215-1231.

Hoefs, J., 2004. Stable Isotope Chemistry. Springer, Berlin 244 p.

Horváth, P., Árkai, P., 2002. Pressure-temperature path of metapelites from the AlgyoFerencszállás area, SE Hungary: thermobarometric constraints from coexisting mineral assemblages and garnet zoning. Acta Geol. Hung. 45, 1-27.

Horváth, F., Dövényi, P., Szalay, Á., Royden, L.H., 1988. Subsidence, thermal, and maturation history of the Great Hungarian plain. In: In: Royden, L.H., Horváth, F. (Eds.), The Pannonian Basin - a Study in basin Evolution, AAPG Memoir, vol. 45. pp. 355-373.

Horwitz, E.P., Chiarizia, R., Dietz, M.L., 1992. A novel strontium selective extraction chromatographic resin. Solvent Extr. Ion Exch. 10, 313-336.

Ilinca, G., 2012. Upper Cretaceous contact metamorphism and related mineralization in Romania. Acta Mineralogica-Petrographica. Abstract Series 7, 59-64.

Ilinca, G., Berza, T., Iancu, V., Seghedi, A., 2011. The Late Cretaceous magmatic and metallogenic belt and the alpine structures of the Western South Carpathians. In: 3rd International Symposium on the Geology of the Black Sea Region, Field Trip Guide Book, 114 p.

Jacquemyn, C., El-Desouky, H., Hunt, D., Casini, G., Swennen, R., 2014. Dolomitization of the Latemar platform: fluid flow and dolomite evolution. Mar. Petrol. Geol. 55, 43-67.

Jiang, L., Cai, C., Worden, R.H., 2016. Multiphase dolomitization of deeply buried Cambrian petroleum reservoirs, Tarim Basin, northwest China. Sedimentology 63 2013-2157.

Jones, G.D., Whitaker, F., Smart, P., Sanford, W., 2004. Numerical analysis of seawater circulation in carbonate platforms: II. The dynamic interaction between geothermal and brine reflux circulation. Am. J. Sci. 304, 250-284.

Juhász, A., Tóth, M., Ramseyer, K., Matter, A., 2002. Connected fluid evolution in fractured crystalline basement and overlying sediments, Pannonian Basin, SE Hungary. Chem. Geol. 182, 91-120.

Kemenci, R., Čanović, M., 1997. Geologic setting of the Pre-Tertiary basement in Vojvodina (Yugoslavia). Part I: the Tisza Mega-unit of North Vojvodina. Acta Geol. Hung. 40, 1-36.

Kókai, J., Pogácsás, G., 1991. Tectono-stratigraphical evolution and hydrocarbon habitat of the Pannonian Basin. In: In: Spencer, A.M. (Ed.), Generation, Accumulation and 
Production of Europe's Hydrocarbons. Special Publication of the European Association of Petroleum Geoscientists, vol. 1. pp. 307-317.

Konrád, Gy., 1998. Synsedimentary tectonic events in Middle Triassic evolution of the SE Transdanubian part of the Tisza Unit. Acta Geol. Hung. 41, 327-342.

Korte, C., Kozur, H.W., Bruckschen, P., Veizer, J., 2003. Strontium isotope evolution of Late Permian and Triassic seawater. Geochem. Cosmochim. Acta 67, 47-62.

Korte, C., Kozur, H.W., Veizer, J., 2005. $\delta^{13} \mathrm{C}$ and $\delta^{18} \mathrm{O}$ values of Triassic brachiopods and carbonate rocks as proxies for coeval seawater and palaeotemperature. Palaeogeography, Palaeoclimatology. Palaeoecology 226, 287-306.

Land, L.S., 1983. The application of stable isotopes to studies of the origin of dolomite and to problems of diagenesis of clastic sediments. In: In: Arthur, M.A., Anderson, T.F., Kaplan, I.R., Veizer, J., Land, L.S. (Eds.), Stable Isotopes in Sedimentary Geology, vol. 10. SEPM, pp. 4.1-4.22 Short Course Notes.

Lavoie, D., Chi, G., Urbatsch, M., Davis, W.J., 2010. Massive dolomitization of a pinnacle reef in the Lower Devonian West Point formation (Gaspe Peninsula, Quebec): an extreme case of hydrothermal dolomitization through fault focused circulation of magmatic fluids. AAPG (Am. Assoc. Pet. Geol.) Bull. 94, 513-531.

Lelkes-Felvári, Gy, Frank, W., Schuster, R., 2003. Geochronological constraints of the variscan, permian-triassic and Eo-alpine (cretaceous) evolution of the Great Hungarian plain basement. Geol. Carpathica 54, 299-315.

Lenkey, L., 1999. Geothermics of the Pannonian basin and its bearing on the tectonics of basin evolution. PhD Thesis. Vrije Universiteit, Amsterdam 215 p.

Lonnee, J., Machel, H.G., 2006. Pervasive dolomitization with subsequent hydrothermal alteration in the clarke lake gas field, Middle Devonian Slave Point Formation, British Columbia, Canada. AAPG (Am. Assoc. Pet. Geol.) Bull. 90, 1739-1761.

Machel, H.G., 2000. Application of cathodoluminescence to carbonate diagenesis. In: Pagel, M., Barbin, V., Blanc, P., Ohnenstetter, D. (Eds.), Cathodoluminescence in Geosciences. Springer, Berlin, Heidelberg, pp. 271-301.

Machel, H.G., Lonnee, J., 2002. Hydrothermal dolomite - a product of poor definition and imagination. Sediment. Geol. 152, 163-171.

Machel, H.G., 2004. Concepts and models of dolomitization: a critical reappraisal. In: In: Braithwaite, C.J.R., Rizzi, G., Darke, G. (Eds.), The Geometry and Petrogenesis of Dolomite Hydrocarbon Reservoirs, vol. 235. Geological Society, London, pp. 7-63 Special Publications.

Mader, D., 1992. Evolution of Palaeoecology and Palaeoenvironment of Permian and Triassic Fluvial Basins in Europe, vol. 1 Gustav Fischer Verlag, Stuttgart Western and Eastern Europe.

Magyar, I., Juhász, G.Y., Szurominé Korecz, A., Sütôné Szentai I, M., 2004. The Tótkomlós Calcareous Marl Member of the Lake Pannon sedimentary sequence in the Battonya-Pusztaföldvár region, SE Hungary. Földtani Közlony 134/4, 521-540 (in Hungarian with English abstract.).

Major, R.P., Lloyd, R.M., Lucia, F.J., 1992. Oxygen isotope composition of Holocene dolomite formed in a humid hypersaline setting. Geology 20, 586-588.

Mansurbeg, H., Morad, D., Othman, R., Morad, S., Ceriani, A., Al-Aasm, I., Kolo, K., Spirov, P., Proust, J.N., Preat, A., Koyi, H., 2016. Hydrothermal dolomitization of the Belchme Formation (Upper Cretaceous), Zagros basin, Kurdistan region of Iraq: record of oil migration and degradation. Sediment. Geol. 341, 147-162.

Mastandrea, A., Perri, E., Russo, F., Spadafora, A., Tucker, M., 2006. Microbial primary dolomite from a Norian carbonate platform: northern Calabria, southern Italy. Sedimentology 53, 465-480.

Matenco, L., Radivojević, D., 2012. On the formation and evolution of the Pannonian Basin: constraints derived from the structure of the junction area between the Carpathians and the Dinarides. Tectonics 31 (TC6007), 31.

Merten, S., Matenco, L., Foeken, J.P.T., Andriessen, P.A.M., 2011. Toward understanding the post-collisional evolution of an orogeny influenced by convergence at adjacent plate margins: late Cretaceous-Tertiary thermometric history of the Apuseni Mountains. Tectonics 30, 28 .

Molnár, L., Tóth, M., Schubert, F., 2015. Structural controls on petroleum migration and entrapment within the faulted basement blocks of Szeghalom Dome (Pannonian Basin, SE Hungary). Geol. Croat. 68, 247-259.

Mullis, J., Dubessy, J., Poty, B., O'Neil, J., 1994. Fluid regimes during late stages of a continental collision: physical, chemical, and stable isotope measurements of fluid inclusions in fissure quartz from a geotraverse in the Central Alps, Switzerland. Geochem. Cosmochim. Acta 58, 2239-2267.

Munz, I.A., Yardley, B.W.D., Gleeson, S.A., 2002. Petroleum infiltration of high-grade basement, South Norway: pressure-temperature-time-composition (P-T-t-X) constraints. Geofluids 2, 41-53.

Naden, J., Kilias, S.P., Leng, M.J., Cheliotis, I., Shepherd, T.J., 2003. Do fluid inclusions preserve $\mathrm{d}^{18} \mathrm{O}$ values of hydrothermal fluids in epithermal systems over geological time? Evidence from paleo- and modern geothermal systems, Milos island, Aegean Sea. Chem. Geol. 197, 143-159.

Nader, F.H., Swennen, R., Ellam, R., 2004. Reflux stratabound dolostone and hydrothermal volcanism-associated dolostone: a two-stage dolomitization model (Jurassic, Lebanon). Sedimentology 51, 339-360.

Nagy, E., 1968. The Triassic of Mecsek mountains. Ann. Inst. Geol. Publ. Hung. 51 (in Hungarian with German abstract).

Neubauer, F., 2002. Contrasting late Cretaceous with Neogene ore provinces in the Alpine-Balkan-Carpathian-Dinaride collision belt. Geol. Soc. Spec. Publ. 204, 81-102.

Nielsen, P., Swennen, R., Keppens, E., 1994. Multiple-step recrystallization within massive ancient dolomite units: an example from the Dinantian of Belgium. Sedimentology 41, 567-584.

Oliver, J., 1986. Fluids expelled tectonically from orogenic belts: their role in hydrocarbon migration and other geologic phenomena. Geology 14, 99-102.

Papp, N., Varga, A., Mészáros, E., Raucsik, B., 2017. A dorozsmai márvány (Tiszaifő́egység) kőzettani újravizsgálata: deformáció és fluidum hatása a mikroszerkezet fejlődésére. Földtani Közlony 147, 337-356 (in Hungarian with English abstract).
Petrash, D.A., Bialik, O.M., Bontognali, T., Vasconcelos, C., Roberts, J.A., McKenzie, J.A., Konhauser, K.O., 2017. Microbially catalyzed dolomite formation: from near-surface to burial. Earth Sci. Rev. 171, 558-582.

Pigott, J.D., Radivojević, D., 2010. Seismic stratigraphy based chronostratigraphy (SSBC) of the Serbian Banat region of the Pannonian Basin. Central European Journal of Geosciences 2/4 481-500.

Pohl, W.L., 2011. Economic Geology: Principles and Practice. Wiley-Blackwell 678p.

Póka, T., Árkai, P., Sajgó, C.S., Horváth, Z.A., Tóth, M.N., Völgyi, L., 1987. Thermal history of Mesozoic basement in Pannonian Basin (S-Hungary). Acta Geol. Hung. 197-229 30/1-2.

Preto, N., Breda, A., Dal Corso, J., Spötl, C., Zorzi, F., Frisia, S., 2015. Primary dolomite in the Late Triassic Travenanzes Formation, Dolomites, Northern Italy: facies control and possible bacterial influence. Sedimentology 62, 697-716.

Qing, H., Bosence, D.W.J., Rose, E.P.F., 2001. Dolomitization by penesaline sea water in early Jurassic peritidal platform carbonates, Gibraltar, western Mediterranean. Sedimentology 48, 153-163.

Radivojević, D., Rundić, L., Knežević, S., 2010. Geology of the Čoka structure in northern Banat (Central Paratethys, Serbia). Geol. Carpathica 61/4, 341-352.

Radke, B.M., Mathis, R.L., 1980. On the formation and occurrence of saddle dolomite. J. Sediment. Petrol. 50, 1149-1168.

Reiser, M.K., Schuster, R., Spikings, R., Tropper, P., Fügenschuh, B., 2016. From nappe stacking to exhumation: Cretaceous tectonics in the Apuseni Mountains (Romania). Int. J. Earth Sci. 106, 659-685.

Ronchi, P., Masetti, D., Tassan, S., Camocino, D., 2012. Hydrothermal dolomitization in platform and basin carbonate successions during thrusting: a hydrocarbon reservoir analogue (Mesozoic of Venetian Southern Alps, Italy). Mar. Petrol. Geol. 29, 68-89.

Rosenbaum, J., Sheppard, S.M.F., 1986. An isotopic study of siderites, dolomites and ankerites at high temperatures. Geochem. Cosmochim. Acta 50, 1147-1150.

Schmid, S.M., Bernoulli, D., Fügenschuh, B., Matenco, L., Schefer, S., Schuster, R., Tischler, M., Ustaszewski, K., 2008. The Alpine-Carpathian-Dinaridic orogenic system: correlation and evolution of tectonic units. Swiss J. Geosci. 101, 139-183.

Schubert, F., Diamond, L.W., Tóth, M., T, 2007. Fluid-inclusion evidence of petroleum migration through a buried metamorphic dome in the Pannonian Basin, Hungary. Chem. Geol. 244, 357-381.

Shepherd, T.J., Rankin, A.H., Alderton, D.H.L., 1985. A Practical Guide to Fluid Inclusion Studies. Blackie and Son Ltd 239 p.

Sheppard, S.M.F., 1986. Characterization and isotopic variations in natural waters. Rev. Mineral. Geochem. 16, 165-183.

Sibley, D.F., Gregg, J.M., 1987. Classification of dolomite rock textures. J. Sediment. Petrol. 57, 967-975.

Simms, M., 1984. Dolomitization by groundwater-flow systems in carbonate platforms. Gulf Coast Association of Geological Societies Transactions 34, 411-420.

Sirat, M., Al-Aasm, I.S., Morad, S., Aldahan, A., Al-Jallad, O., Ceriani, A., Morad, D., Mansurbeg, H., Al Suwaidi, A., 2016. Saddle dolomite and calcite cements as records of fluid flow during basin evolution: Paleogene carbonates, United Arab Emirates. Mar. Petrol. Geol. 74, 71-91.

Smith Jr., L.B., 2006. Origin and reservoir characteristics of Upper Ordovician Trenton-Black River hydrothermal dolomite reservoirs in New York. AAPG (Am. Assoc. Pet. Geol.) Bull. 90, 1691-1718.

Spötl, C., Vennemann, T.W., 2003. Continuous-flow IRMS analysis of carbonate minerals. Rapid Commun. Mass Spectrom. 17, 1004-1006.

Stasiuk, L.D., Snowdon, L.R., 1997. Fluorescence micro-spectrometry of synthetic and natural hydrocarbon fluid inclusions: crude oil chemistry, density and application to petroleum migration. Appl. Geochem. 12, 229-241.

Stevanović, Z., Dulić, I., Dunčić, M., 2015. Some experiences in tapping deep thermal waters of the Triassic karstic aquifer in the Pannonian Basin of Serbia. Central European Geology 58, 50-61.

Sun, S.Q., 1994. A reappraisal of dolomite abundance and occurrence in the phanerozoic. J. Sediment. Res. 64, 396-404.

Szabó, B., Schubert, F., Tóth, M., 2009. Paleofluid evolution of the fractured basalt hydrocarbon reservoir in the Üllés-Ruzsa-Bordány area, SE Hungary. Central European Geology 52, 299-323.

Szabó, B., Schubert, F., Tóth, M., T, Steinbach, G., 2016. Palaeofluid evolution in a fractured basalt hosted reservoir in the Üllés-Ruzsa-Bordány area, southern sector of the Pannonian Basin. Geol. Croat. 69, 281-293.

Szederkényi, T., 1984. The Crystalline Basement of the Great Hungarian Plain and its Geologic Connections. DSc Thesis. Budapest (in Hungarian).

Szederkényi, T., 2007. Banatite association in the basement of the southern part of the Great Hungarian Plain. Acta GGM Debrecenica 2, 67-77.

Szederkényi, T., Haas, J., Nagymarosy, A., Hámor, G., 2013. Geology and history of evolution of the Tisza mega-unit. In: Haas, J. (Ed.), Geology of Hungary. SpringerVerlag, pp. 103-148.

Szulc, J., 2000. Middle Triassic evolution of the northern Peri-Tethys area as influenced by early opening of the Tethys Ocean. Ann. Soc. Geol. Pol. 70, 1-48.

Szurominé Korecz, A., Garaguly, I., Szente, I., Varga, A., Raucsik, B., 2018. "Oasis in the desert" - a particularly rich fossil assemblage from the fossil-poor Szeged Dolomite Formation, Üllés (Szeged Basin, Hungary). Földtani Közlony 148, 119-124 (in Hungarian with English abstract).

Tari, G., Dövényi, P., Dunkl, I., Horváth, F., Lenkey, L., Stefanescu, M., Szafián, P., Tóth, T., 1999. Lithospheric structure of the Pannonian Basin derived from seismic, gravity and geothermal data. In: In: Durand, B., Jolivet, L., Horváth, F., Séranne, M. (Eds.), The Mediterranean Basins: Tertiary Extension within the Alpine Orogen, vol. 156. Geological Society, London, pp. 215-250 Special Publications.

Teleki, P.G., Mattick, R.E., Kókai, J. (Eds.), 1994. Basin Analysis in Petroleum Exploration. A case study from the Békés basin, Hungary. Kluwer Academic Publishers 330 p. 
Török, Á., 1997. Triassic ramp evolution in southern Hungary and its similarities to the germano-type Triassic. Acta Geol. Hung. 40, 367-390.

Török, Á., 1998. Controls on development of mid-Triassic ramps: examples from southern Hungary. In: In: Wright, V.P., Burchette, T.P. (Eds.), Carbonate Ramps, vol. 149. Geological Society, London, pp. 339-367 Special Publications.

Tóth, M.T., 2008. Repedezett, metamorf fluidumtárolók az Alföld aljzatában. DSc Thesis. Szeged 399 p. (in Hungarian).

Tóth, M.T., Fiser-Nagy, Á., Schubert, F., 2017. Petrology and structural evolution of the metamorphic basement of the Pannonian Basin. In: In: Pál-Molnár, E. (Ed.), Acta Minerologica-Petrographica Field Guide Series, vol. 32. pp. 80-92.

Vasconcelos, C., McKenzie, J.A., Bernasconi, S., Grujic, D., Tien, A.J., 1995. Microbial mediation as a possible mechanism for natural dolomite formation at low temperatures. Nature 377, 220-222.

Vlad, S.N., 1997. Calcic skarns and transversal zoning in the Banat mountains, Romania: indicators of an Andean-type setting. Miner. Deposita 32, 446-451.

Warren, J.K., 2000. Dolomite: occurrence, evolution and economically important associations. Earth Sci. Rev. 52, 1-81.

Warren, J.K., 2006. Evaporites: Sediments, Resources and Hydrocarbons. Springer BerlinHeildelberg, New York 1035 p.
Whitaker, F.F., Smart, P.L., 1993. Circulation of saline groundwaters in carbonate platforms: a review and case study from the Bahamas. In: Horbury, A.D., Robinson, A.G. (Eds.), Diagenesis and Basin Development. AAPG Stud Geol, Tulsa, pp. 113-132.

Woodcock, N.H., Mort, K., 2008. Classification of fault breccias and related fault rocks. Geol. Mag. 145, 435-440.

Whitaker, F.F., Smart, P.L., Jones, G., 2004. Dolomitization: from conceptual to numerical models. In: In: Braithwaite, C.J.R., Rizzi, G., Darke, G. (Eds.), The Geometry and Petrogenesis of Dolomite Hydrocarbon Reservoirs, vol. 235. Geological Society, London, pp. 99-139 Special Publications.

Wright, D.T., 2000. Benthic microbial communities and dolomite formation in marine and lacustrine environments — new dolomite model. In: Glenn, C.R., Pevot-Lucas, L., Lucas, J. (Eds.), Marine authigenesis: from Global to Microbial. SEPM Special Publication, pp. 7-20.

Yardley, B.W.D., Cleverley, J.S., 2013. The Role of Metamorphic Fluids in the Formation of Ore Deposits, vol. 393. Geological Society, London, pp. 117-134 Special Publications.

Zhao, H., Jones, B., 2012. Genesis of fabric-destructive dolostones: a case study of the Brac Formation (Oligocene), Cayman Brac, British West Indies. Sediment. Geol. $267-268,36-54$. 